\title{
First occurrence of the enigmatic peccaries Mylohyus elmorei and Prosthennops serus from the Appalachians: Latest Hemphillian to Early Blancan of Gray Fossil Site, Tennessee
}

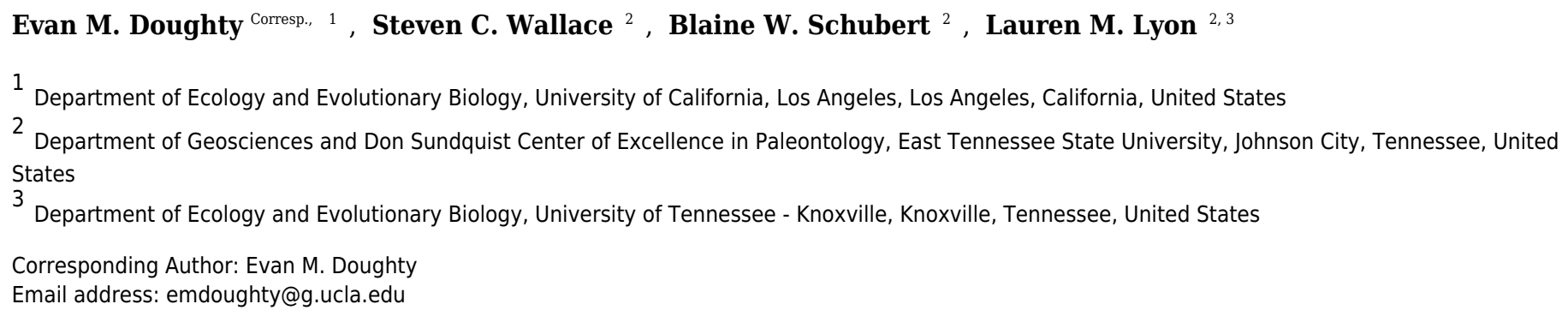

Two peccary species, Mylohyus elmorei and Prosthennops serus are described from the medium-bodied fauna of the Gray Fossil Site (GFS) of northeastern Tennessee. This site, recognized as an oak-hickory forest, is latest Hemphillian or earliest Blancan based on mammalian biochronology, with an estimated age of 4.9-4.5 Ma. The GFS represents the only site outside the Palmetto Fauna of Florida with M. elmorei, greatly expanding the species range north over $920 \mathrm{~km}$, well into the Appalachian region. This is also the first Appalachian occurrence of the relatively widespread $P$. serus. Our understanding of intraspecific variation for both $M$. elmorei and $P$. serus is expanded due to morphological and proportional differences found in cranial and dental material from the GFS, Tyner Farm locality, Palmetto Fauna, and within the literature. The GFS $M$. elmorei material represents the most complete mandible and second cranium for the species, and preserve intraspecific variation in the length of the diastema, dental proportions, and the complexity of the cuspules hypoconulid complex. Similarly, mandibular material from the GFS for $P$. serus exhibited larger dentitions and a greater degree of robustness than currently recognized for the species. 
1 First occurrence of the enigmatic peccaries Mylohyus elmorei and Prosthennops serus from

2 the Appalachians: Latest Hemphillian to Early Blancan of Gray Fossil Site, Tennessee

3 Evan M. Doughty ${ }^{1}$, Steven C. Wallace ${ }^{2}$, Blaine W. Schubert ${ }^{2}$, and Lauren M. Lyon ${ }^{2,3}$

$4{ }^{1}$ Department of Ecology and Evolutionary Biology, University of California - Los Angeles, Los

$5 \quad$ Angeles, California United States

$6{ }^{2}$ Department of Geosciences and Don Sundquist Center of Excellence in Paleontology, East

7 Tennessee State University, Johnson City, Tennessee United States

$8{ }^{3}$ Department of Ecology and Evolutionary Biology, University of Tennessee - Knoxville,

9 Knoxville, Tennessee United States

12 Corresponding Author: Evan Doughty

13103 Hershey Hall, 612 Charles E. Young Drive East 
First occurrence of the enigmatic peccaries Mylohyus elmorei and Prosthennops serus from the Appalachians: Latest Hemphillian to Early Blancan of Gray Fossil Site, Tennessee Evan M. Doughty ${ }^{1}$, Steven C. Wallace ${ }^{2}$, Blaine W. Schubert ${ }^{2}$, and Lauren M. Lyon ${ }^{2,3}$

${ }^{1}$ Department of Ecology and Evolutionary Biology, University of California - Los Angeles, Los Angeles, California United States

${ }^{2}$ Department of Geosciences and Don Sundquist Center of Excellence in Paleontology, East Tennessee State University, Johnson City, Tennessee United States

${ }^{3}$ Department of Ecology and Evolutionary Biology, University of Tennessee - Knoxville, Knoxville, Tennessee United States

\section{Abstract}

Two peccary species, Mylohyus elmorei and Prosthennops serus are described from the medium-bodied fauna of the Gray Fossil Site (GFS) of northeastern Tennessee. This site, recognized as an oak-hickory forest, is latest Hemphillian or earliest Blancan based on mammalian biochronology, with an estimated age of 4.9-4.5 Ma. The GFS represents the only site outside the Palmetto Fauna of Florida with M. elmorei, greatly expanding the species range north over $920 \mathrm{~km}$, well into the Appalachian region. This is also the first Appalachian occurrence of the relatively widespread P. serus. Our understanding of intraspecific variation for both M. elmorei and P. serus is expanded due to morphological and proportional differences found in cranial and dental material from the GFS, Tyner Farm locality, Palmetto Fauna, and within the literature. The GFS M. elmorei material represents the most complete mandible and second cranium for the species, and preserve intraspecific variation in the length of the diastema, dental proportions, and the complexity of the cuspules hypoconulid complex. Similarly, 
43 mandibular material from the GFS for P. serus exhibited larger dentitions and a greater degree of

44 robustness than currently recognized for the species.

45

46

47

48

49

50

51

52

53

54

55

56

57

58

\section{Introduction}

Tayassuidae, a family of pig-like artiodactyls endemic to the New World, is geographically and temporally widespread (Wright, 1998). East of the Mississippi River, however, late Hemphillian to early Blancan faunas are rare. The Palmetto Fauna of Florida is similar in age to Gray Fossil Site (GFS), and is represented by an aggregation of multiple mine localities (e.g. Fort Green Mine, Palmetto Mine, Payne Creek, Saddle Creek Mine, and South

Pierce quarries) within the Central Florida Phosphate District of Polk, Hillsborough, Manatee, and Hardee counties (Fig. 1) (Wright \& Webb, 1984; Wright, 1989; Hulbert, 2001; Webb et al., 2008). Outside of the Palmetto Fauna, the eastern record is represented by the Pipe Creek paleosinkhole of Indiana (Hh4) (Farlow et al., 2001; Prothero \& Sheets, 2013), the Mauville local fauna of Alabama (Hh2) (Hulbert \& Whitmore, 2006), and the Tyner Farm locality of Florida (late Hh1 to early Hh2) (Hulbert \& Whitmore, 2006; Hulbert et al., 2009a). Specifically, the Tyner Farm and Mauville local faunas both chiefly exhibit Prosthennops serus (Hulbert \& Whitmore, 2006; Hulbert et al., 2009a) whereas the Pipe Creek fauna is attributed by Prothero and Sheets (2013) to include Protherohyus brachydontus (=Catagonus brachydontus; see Parisi Dutra et al., 2017) and Platygonus pollenae. Tayassuids are also identified within the fauna present at the Gray Fossil Site (GFS), with Parmelee et al. (2002) suggesting cf. Protherohyus sp. However, based on the fragmentary nature of the material recovered at that time, subsequent workers identified GFS peccaries to the family level only (e.g., Wallace \& Wang, 2004; DeSantis \& Wallace, 2008). 
United States that represents the latest Hemphillian (Hh4) to earliest Blancan (Wallace \& Wang, 2004; Samuels, Bredehoeft \& Wallace, 2018). An oak-hickory forest surrounded the approximately $2.6-3.5$ ha lacustrine deposit, which has a maximum depth of $42 \mathrm{~m}$; the GFS is comprised of up to eleven paleosinkholes within the Cambrian to Ordovician dolostone of the Knox Group (Shunk, Driese \& Clark, 2006; Whitelaw et al., 2008). For a full review of the geology of GFS see Shunk, Driese \& Clark (2006) and Shunk et al. (2009). Early descriptions from the GFS constrain the site to 7 to $4.5 \mathrm{Ma}$, based on the presence of Teleoceras and Plionarctos, but a recent description of Gulo sandorus from the site included a list of additional fauna which suggest an lower age limit of approximately 4.9 Ma (Wallace \& Wang, 2004; Samuels, Bredehoeft \& Wallace, 2018). This diverse fauna and flora from this site appears to suggest that the oak-hickory forest surrounding the lacustrine system was a refugium for otherwise disappearing taxa due to the spread of grasslands throughout other regions of the United States (Wallace \& Wang, 2004; DeSantis \& Wallace, 2008). Despite bearing taxa with Asiatic affinities (e.g., Wallace \& Wang, 2004; Liu \& Jacques, 2010; Ochoa et al., 2012)—much of the fauna of the GFS exhibits great similarity to that of the Palmetto Fauna of Florida (Hulbert et al., 2009b; Bourque \& Schubert, 2015). This includes Tapirus polkensis, Teleoceras sp., Plionarctos sp., and Alligator sp. (Wallace \& Wang, 2004; Webb et al., 2008; Short, 2013). These similarities extend to the previously unstudied GFS peccary material and the multiple tayassuid taxa recognized within the Palmetto Fauna (Wright \& Webb, 1984; Wright, 1989, 1998; Hulbert et al., 2009a). Considering the above, analysis of the GFS tayassuid material provides a unique opportunity to better understand the latest Hemphillian to earliest Blancan of the Appalachian 
88 region and its relation to other similarly aged sites within eastern North America. Here we report

89 the first occurrence of Mylohyus elmorei outside the Palmetto Fauna of Florida, recognize

90 Prosthennops serus within Appalachia, and discuss the implications of multiple tayassuid

91 specimens occurring at the GFS and the region. Additional tayassuid material is recognized

92 within GFS, however, more work is required to verify a full designation.

\section{Methods and Materials}

$$
\text { Linear measurements (mm) follow Von den Driesch (1976), whereas nomenclature }
$$

regarding skeletal morphology follows Woodburne (1968), Sisson and Grossman (1975), and Wright (1989, 1991, 1998) (Fig. 2). Dental measurements and nomenclature were adapted from Wright and Webb (1984) and Wright (1991) (Fig. 3). Images of specimens within the University of Florida Museum of Natural History collections were taken with a Nikon d5100 camera using a Nikon AF-S Micro-NIKKOR 60mm f/2.8G ED lens and are available on the FLMNH websitewww.flmnh.ufl.edu/vertpaleo-search/—-through NSF grant CSBR 1203222 (Sean Moran, pers. comms., 2015). GFS specimens were photographed using a Canon EOS Rebel Xsi camera and tripod or MK DigitalDirect Photo-eBox Plus Digital Lighting System. All images were edited using GIMP 2.0, Inkscape 0.91, and Adobe Photoshop CS2 and CS5.

Specimen Repositories-ETMNH, East Tennessee State University Museum of Natural History-Fossil Collections, Gray, Tennessee; ETVP, East Tennessee State University Museum of Natural History-Comparative Collection, Johnson City, Tennessee; UF, Division of Vertebrate Paleontology, Florida Museum of Natural History, University of Florida, Gainesville, Florida; UF/TRO, Timberlane Research Organization, Lake Wales, Florida (part of the John Waldrop Collection now housed at the Division of Vertebrate Paleontology, Florida Museum of Natural History, Gainesville, Florida). 


\section{RESULTS}

\section{Systematic Paleontology}

113

114

115

116

117

118

119

120

121

122

123

124

125

126

127

128

129

130

131

132
Class MAMMALIA Linneaeus, 1758

Order ARTIODACTYLA Owen, 1848

Family TAYASSUIDAE Palmer, 1897

Subfamily TAYASSUINAE Palmer, 1897

Genus Mylohyus Cope, 1889

Mylohyus elmorei (White, 1942) Wright \& Webb, 1984

Holotype-MCZ 3805: partial L. ramus with p2-m3.

Referred Specimens_-ETMNH 7279: L. M2 with partial maxilla; ETMNH 8046: reconstructed partial maxilla with L. and R. P2-M3, partial mandible with L. p3-m3 and R. p2- m3; ETMNH 17219: partial L. p3; ETMNH 19281: L. m2; UF/TRO 440, UF 203540: isolated R. M3. Additional referred specimens listed by White (1942) and Wright and Webb (1984) (Table S1).

Description - Cranium of ETMNH 8046 exhibits a partial maxilla with the left portion of the laterally convex rostrum extending from the P2 to the anterior margin of the canine buttress (Fig. 4). Buttress exhibits an irregular shape; bearing both triangular and hemispherical outlines in dorsal and lateral views, respectively. A deep, anteroventrally tapering concavity separates the buttress and the rest of the rostrum. Concavity is bordered laterally by a thin anteromedial to posterolaterally oriented crest that increases in robustness posterodorsally until merger with the dorsal apex of the buttress. Occlusal surface of the anterior buttress is comprised of a triangular patch of relatively flat cortical bone that is separated from the bulbous, inflated lateral margins of the buttress by a shallow ridge. Left canine alveolus is intact and ellipsoid in outline but canine 
133 is not present. Post-canine diastema between the posterior boundary of the canine alveoli and P2

134 is long - approximately $110 \%$ of total cheek tooth series length (Table 1) — and contains a

135 shallow diastemal crest that trends its full length. Rostrum exhibits a laterally extending crest

136 along the dorsal surface that is the origination of pneumatic zygoma. Crest is bulbous and

137 inflated along its anterodorsal margin whereas the inferior boundary is marked by

138 posteroventrally trending curvature of the maxillary bone. No internal structure of this portion of

139 the zygoma is preserved; however, a deep sinuous depression is present posteromedial of the

140 crest. A shallow to moderate supraorbital sulci trends the length of the dorsolateral surface of

141 the rostrum, originating posteromedial to the lateral crest and terminating anterior and dorsal of

142 the left canine buttress. Ventral surface of rostrum exhibits a palatine sulcus that extends medial

143 of the $\mathrm{P} 2$ to the canine buttresses. The remaining medial portion of the palate posterior of the P2

144 is reconstructed with the posterior portion of the sulci lacking. Maxillopalatine region along the

145 dorsal surface of the palate is sinuous. Within the maxillopalatine labyrinth, the thin-

146 approximately $1.52 \mathrm{~mm}$ width—nasal septum diverges approximately $7.5 \mathrm{~mm}$ anterior of the $\mathrm{P} 2$.

147 Internal surface of maxilla dorsal and anterior of the P2 appears to exhibit thin, shallow

148 anteroposteriorly trending sulci. Nasal passage is incomplete with the medially projecting

149 remnants indicating a posteriorly constricting tubular profile that trends posterodorsally from

150 medial of the canine buttress to medial of the origination of the zygoma, dorsal to the chambers

151 of the maxillopalatine labyrinth. Vomeroethmoid chamber is directly ventral of the nasal

152 passage and lateral of the nasal septum. Lateral expansion of the chamber is evident posterior of

153 the canine buttresses due the lateral bulging of the cortical bone of the maxilla, with the external

154 surface being convex whereas the interior surface is comprised of a moderate elliptical

155 depression. Medial surface of the rostral cortical bone is pockmarked by numerous intersecting 
156 sulci of very shallow depths. Further analysis of the maxillopalatine labyrinth as described by

157 Wright (1991) is not possible due to the lack of preservation. but lacking the anterior margin of the symphysis, right mandibular condyle, and right coronoid process (Fig. 5). Canine alveoli and the anterior margin of symphysis are missing. Despite being incomplete, the symphysis is relatively gracile and elongate with a moderate to deep, medially positioned spout-like concavity along its anteroposterior length that bears similarities with the mandibular spout present in ground sloths (e.g. Mcdonald and De Muizon, (2002), De Muizon et al., (2003)). This mandibular concavity is laterally bounded by raised ridges that trend posteriorly and then dorsoposteriorly until the base of the p2. A single mental foramen is evident ventral to the trigon of the $\mathrm{p} 4$ on the labial surface of the right rami. Two genial pits are positioned within a shallow laterally trending genial fossa along the posterior surface of the symphysis medial to the rami. A shallow transverse ridge trends along the ventral-most edge of the symphasis ventral to the genial fossa. Distance between anterior edge of the $\mathrm{p} 2$ to the posterior edge of the symphysis is $\sim 43.5 \mathrm{~mm}$. Rami are mediolaterally gracile with a relatively consistent depth along the cheek tooth series, however, the region in contact with the cheek teeth is medially inflated relative to the ventral margin of the rami (Table 2). Ventral surface of the rami retains a relatively similar width leading to the development of a shallow digastric fossa and submandibular fossa between the $\mathrm{p} 2$ and $\mathrm{m} 3$ which opens posteriorly into the shallow pterygoid fossa. Ventral to the $\mathrm{m} 3$, the left mandibular foramen, despite being damaged, appears to be ellipsoid in profile as it opens into a moderate to shallow, anteroposteriorly trending mylohyoid groove. A small mental foramen is positioned ventral to the anterior cusps of the $\mathrm{p} 4$ along the labial surface of the right rami. Coronoid process exhibits a triangular outline with a shallow to 
179 moderately deep masseteric fossa. Angle originates approximately ventral to the posterior

180 margin of the $\mathrm{m} 3$ and exhibits a shallow pterygoid fossa that is bounded posteroventrally by a

181 shallow ridge.

182 Specimen (ETMNH 8046) exhibits moderate wear on the teeth of the upper and lower

183 dentition (Fig. 6 and Fig. 7). Premolars of the lower and upper dentition exhibit a mostly

184 quadrate, molariform condition with moderate anterior and posterior cingula. Exhibiting a more

185 squared to trapezoidal outline, the P2 bears a longer labial edge relative the lingual edge due to a

186 strong, lingually terminating anterior cingulum along the anterior surface of paracone (Table 1).

187 Paracone and anterior cingulum are merging through wear on the right P2 along the anterolingual

188 moiety of the cusp. However, this merger is incomplete as a shallow furrow still separates the

189 median to lingual moiety of the cusp. Trigon and talon are separated by a moderate to deep

190 median valley. Metacone is conic in outline with the left P2 exhibiting slight merger of the cusp

191 with the posterior cingulum along the posterolignual-most edge of the cusp; a shallow furrow

192 separates the posterior edge of the cusp from the cingulum. Hypocone is worn to merger with

193 the posterior cingulum which reduces labially until its termination along the posterolabial to

194 labial edge of the metacone. An ellipsoid fossette is visible on the anterior moiety of the

195 hypocone on the left P2.

Third and fourth upper premolars of ETMNH 8046 exhibit similar morphology except for

197 the latter being slightly larger. Both exhibit a merger of the protocone and the weak anterior

198 cingulum through wear. Protocone is merging anterolabially with the heavily worn paraconule is

199 whereas the paracone remains separated from either feature by a moderate furrow. Metaconule

200 and hypoconule are positioned anteromedial and posteromedial to the hypocone and metacone,

201 respectively. Both metaconule and hypoconule merge with the hypocone through wear. 
202 Ellipsoid to semilunar fossettes are located at the center of the metaconule, hypoconule, and

203 hypocone. Metacone is separated from the remainder of the talon by a very shallow furrow.

204 Posterior cingulum is moderate, trending the entire posterior edge of all but the left P3 which

205 exhibits chipping of the enamel posterior to the metacone. A depression is evident along the

206 posterior cingulum of the left $\mathrm{P} 4$ and the anterior cingulum of the $\mathrm{M} 1$, which may represent a

207 cavity or pathology.

Upper molars of ETMNH 7279 and ETMNH 8046 exhibit typical tayassuid morphology

209

210

211

212

213

214

215

216

217

218

219

220

221

222

223

224 due to the square to rhombohedral placement of the four primary cusps and strong to moderate anterior and posterior cingula. Left M1 exhibits a continuation of the depression of the P4 at the site of paraconule on the anterior cingulum. Paraconules on both the M1 and M2 (of both ETMNH 7279 and ETMNH 8046) are merging with the paracone through wear, whereas the M3 only exhibits merger of the paraconule with the anterior cingulum. All molars exhibit labial cingula that are weak to moderate along the anterolateral edge of the paracone, within the deep median valleys between the labial cusps, and along the posterolateral surface of the metacone. A single accessory cuspule populates the labial cingulum within the median valley of the M2 and M3, however, the cuspule in the latter is reduced. Both the trigon and talon have been almost completely worn into irregularly-shaped, transversely elongate fossettes in the M1. Talon fossette exhibits a partially separation of the metacone fossette from the rest of talon fossette by a thin remnant of lingual to posteriorly bounding enamel (right) or raised dentin (left) that opens anterolingually. Alternatively, the M2 only exhibits merger of the hypocone and metacone with the hypoconule and the metaconule, respectively. Metaconule is heavily worn in the M3 but remains separated from the metacone and hypocone by shallow furrows. In the M2 the hypoconule is worn flat with the posterior cingulum and is merging with the hypocone. Posterior 
225 cingulum is strongly developed and bears a small accessory cuspule at its termination at the

226 posterolabial edge of the metacone. Four distinct cusps and conules are present on the

227 moderately worn hypoconulid complex of the M3 in addition to the hypoconulid. Three of these

228 accessory cuspules are arranged in a transverse row along the posterior boundary of the complex

229 and are merging through wear. The remaining cuspule is positioned directly labial to the

230 hypoconule. Posterior cingulum is reduced to a small but strong shelf positioned posterolingual

231 of the metacone and dominated by two small accessory cuspulids.

232 Lower premolars of ETMNH 8046 exhibit similar morphology to the upper premolars;

233 however, the p2 is more transversely constricted (Table 2). In total, each premolar displays a

234 fully formed protoconid, metaconid, hypoconid, and entoconid. Protoconid and metaconid of the

235 p2 are distinct, but not fully bifurcated as in the p3 - in both ETMNH 8046 and ETMNH

$236 \quad 17219$ - and the $\mathrm{p} 4$. Anterior cingula are variable between premolars, being weakly developed

237 but become inflated at the site of the paraconulid in the p3 and p4. Metacone of the p3 and p4

238 exhibits an ellipsoid to rectangular posterolabial extension that is distinct from the parent cusp in

239 ETMNH 17219. Premolar talonid basins exhibit a metaconulid and hypoconulid that are

240 positioned directly anteromedial and posteromedial of the entoconid and hypoconid,

241 respectively, in a 'cross-'or 'plus-' shaped configuration. Posterior cingulum exhibits additional

242 crenulation and very small accessory cuspules on the $\mathrm{p} 4$ that are not present on the $\mathrm{p} 3$. A slight

243 elevation of the trigonid cusps, relative to the talonid cusps, is evident in ETMNH 17219

244 whereas ETMNH 8046 lacks this feature due to a greater degree of wear.

Heavily worn, the m1 of ETMNH 8046 exhibits complete obliteration of all cusps and conules. Trigonid and the anterior cingulum are worn to a single transversely trending fossette.

247 Wear of the talonid produces an ellipsoid fossette with ellipsoid extensions into the positions of 
248 the entoconulid and hypoconulid. Trigonid and talonid fossettes are separated from one another

249 by a thin band of enamel on the right $\mathrm{m} 1$. However, the left $\mathrm{m} 1$ exhibits merger of the trigonid

250 and talonid fossettes in tandem with the posterior cingulum almost being completely worn.

251 Moderately deep, semispherical concavities are present within the dentin at the positions of the

252 metaconid and entoconid of the right $\mathrm{m} 1$ and the posterior margin of the posterior cingulum of

253 the left $\mathrm{m} 1$ indicating a potential pathology.

Similar to the $\mathrm{m} 1$ in general outline and apparent cusp arrangement, the $\mathrm{m} 2$ and $\mathrm{m} 3$ are

less worn. Anterior cingulum is moderate to strong in both ETMNH 8046 and ETMNH 19281.

Angular wear facets along the surface of the protoconid and metaconid merge the cusps

257

258

anteriorly with the anterior cingulum. Both cusps exhibit a central fossette along the occlusal surface, with the protoconid exhibiting an anterolabial extension of the fossette into the median of the anterior cingulum. Posterolateral projection of the metaconid is merged with the main body of the metaconid through wear in both ETMNH 8046 and ETMNH 19281. Hypoconid is separate from the hypoconulid in ETMNH 19281, but is merged through wear in ETMNH 8046. Hypoconulid is separate in both specimens, however, it is merged with the strong posterior cingulum through wear in ETMNH 8046. Despite being slightly less worn, the m3 exhibits a similar positioning of the primary cusps as the $\mathrm{m} 2$ with the presence of a hypoconulid complex. Four distinct cusps or conulids, including the hypoconulid, are positioned on the hypoconulid complex of the right $\mathrm{m} 3$; whereas the left $\mathrm{m} 3$ exhibits five conules in ETMNH 8046. On both m3's the hypoconulid is positioned posteromedian of the talonid with the accessory cuspules, of variable size and profile, being positioned posterior to the hypoconulid in a circular arrangement.

Comparisons-Material from the GFS is referred to Mylohyus due to the presence of distinct apomorphies; specifically, a long diastema that exceeds the length of the cheek tooth row and 
271 fully molarized premolars (Wright, 1991, 1998). This material is referred to M. elmorei on the

272 grounds that it bears notable similarity to material previously collected from the Palmetto fauna

273 of Florida (Table S1). Dental morphologies of ETMNH 8046 and a cast of the holotype, MCZ

2743805 (labeled UF 57280), display very few differences outside of the latter exhibiting relatively

275 larger dental dimensions for all but the $\mathrm{p} 4$. This is due to the holotype having less robust

276 cingula — both anterior and posterior — on the p4 than that of ETMNH 8046. A concave

277 depression on the lingual surface of the $\mathrm{m} 1$ metaconid is also evident in the holotype cast. Other

278 potential differences may be obscured due to the p3 missing its talonid on the holotype.

279 Alternatively, the p3 of UF/TRO 412 displays variation of the talonid: with the entoconulid and

280 hypoconulid being merged into a single anteroposterior trending rectangular cuspule that is

281 positioned median of the entoconid and hypoconid. Distinct posterolabial extensions of the

282 metaconid on the p3 and p4 are only present in UF/TRO 412, UF 293749, and UF 57280.

283 Moderate wear obscures the number of accessory cuspules present on the posterior cingula of the

284 p4 in ETMNH 8046, UF/TRO 412, and UF 57280. Five accessory cuspules of variable size are

285 visible on the posterior cingulum of the p4 on UF 294729. Hypoconulid complex exhibits a

286 substantial amount of variation between the observed specimens. Three cuspules (including the

287 hypoconulid) are evident on UF/TRO 412, whereas UF 57280 and ETMNH 8046 exhibit

288 hypoconulid complexes comprised of four and five, respectively.

12265. Both ETMNH 8046 and UF 12265 exhibit a very elongate post canine diastema, the

former being $\sim 109 \%$ of the cheek tooth row, whereas the latter exhibits a diastema of only

$292 \sim 101 \%$ (Fig. 8). Origination of the triangular zygoma is positioned directly dorsal to the P2 in

293 both specimens; however, further comparisons are not possible due to the fragmentary nature of 
294 ETMNH 8046. Little deviation outside of tooth dimensions of the P2-M2 is present between

295 ETMNH 8046 and UF 12265. Consequently, the M3 exhibits a greater degree of variation with

296 ETMNH 8046 exhibiting a wider talon and hypoconule complex, relative to the trigon, than

297 those of UF 12265, UF 203540, and UF/TRO 440. Further differences between the specimens

298 are evident in the lateral flaring of the canine buttress in UF 12265 that is not present in ETMNH

2998046 (Fig. 9). Specifically, the flaring in UF 12265 begins on the approximate anteroposterior

300 midpoint of the postcanine diastema, whereas the buttresses flare develops within the anterior-

301 most portion of the postcanine diastema in ETMNH 8046. These dental and cranial differences

302 could be indicative of these specimens representing different species; however, this seems

303 premature because the GFS specimen will be the second partial cranium reported for the species.

304 As such, the variation (geographic, temporal, sexual, or individual) present within the species is

305 unknown, however comparisons could be made to known degree of intraspecific variation in

306 Mylohyus fossilis and extant species to show that this range of variation is more likely

307 intraspecific rather than interspecific.

cf. Mylohyus elmorei (White, 1942) Wright \& Webb, 1984

Referred Specimens-ETMNH 6767: partial L. zygoma and maxillary fossa.

Description - Highly sinuous cortical bone is evident in both the proximal and distal

311

312

313

314

315

316

reconstructions of the left zygomatic wing, ETMNH 6767. Comprised of three associated portions of a left zygomatic wing, ETMNH 6767 exhibits the squamosal portion of zygoma with an intact mandibular fossa. A lambdoid crest of moderate depth projects posterodorsally from the confluence of the zygomatic wing and jugal bar. Ventrolaterally oriented, the semilunar mandibular fossa is positioned posterior and ventral to the zygoma, with the concave-most margin of the fossa being approximately equal in level with the zygoma. Zygoma remnants 
317 exhibit a triangular dorsal outline of the posterior margin where the inflated portion reduces

318 posterodorsally to a thin edge. Deeply incised cortical bone demarcates the partial, circular to

319 ellipsoid, rostral muscle fossa on the ventral surface of the reconstructed segments of the main

320 distal body of the zygoma. Another muscle attachment is evident along the flat dorsal surface of

321 this distal section in the form of an anteromedially trending muscle scar, comprised of an

322 elongate raised ridge. It should be noted that both ETMNH 6767 and ETMNH 8046 could

323 potentially be a single individual, however, given the spatial distribution of the two specimens

324 they are considered separate for this analysis.

325 Comparisons - Despite being comprised of reconstructed fragments, ETMNH 6767 appears to

326 exhibit affinities to UF 12265 due to the mandibular fossa being positioned posterior and ventral

327 to the posterior margin of the triangular zygomatic wing. This separates ETMNH 6767 from

328 either Protherohyus brachydontus and Prosthennops serus, which exhibit a mandibular fossa that

329 is positioned directly ventral of the trailing edge of the wing-like zygoma. Moreover, the

330 anterolateral to posteromedial angle of the posterior margin of ETMNH 6767 further mirrors UF

331 122665. Conclusive assignment of ETMNH 6767 is withheld as a larger and less fragmentary

332 sample of $M$. elmorei is needed for a reliable taxonomic assignment.

Genus Prosthennops Gidley, 1904

Holotype-AMNH 8511: partial mandible with R. i1,2, p2-m1 and L. i1-3, p2-m3.

Referred Specimens-ETMNH 410: isolated L. p4; ETMNH 5615: partial mandible with L.

338 in Hulbert et al. (2009a) and Schultz and Martin (1975) (Table S1). 
339 Description-As a partial mandible, ETMNH 5615 (Fig. 10) is lacking the coronoid, condylar,

340 and angular processes. Mandibular symphysis is long with the dorsal surface exhibiting a

341 moderately deep spout-like concavity with a posteroventral orientation. This mandibular

342 concavity is bounded by raised ridges of cortical bone that trend the length of the postcanine

343 diastema. Projecting posteriorly, the post-canine diastema is moderate in length — approximately

$34462.4 \%$ of total cheek tooth series length (Table 3). Paired genial pits are positioned along the

345 posterior margin of the symphysis where rami merge to form the symphysis. A single mental

346 foramen is located along the anteroventral surface of the symphysis posteroventral of the i2

347 along both rami. Another set of foramina are evident along the postcanine diastema with the left

348 bearing three foramina and the right bearing two foramina. Rami laterally broaden in a

349 posterodorsal trend beginning ventral of $\mathrm{p} 3$ before being level with the base of the m3. Posterior

350 extent of the broadening appears to be evident along the labial edge of the left $\mathrm{m} 3$, however, due

351 to this region being heavily reconstructed this is tentative. Coracoid process originates directly

352 posterior of the $\mathrm{m} 3$. Angle appears to originate ventral of the $\mathrm{m} 3$; however, the reconstruction of

353 this portion of the rami may be skewing this observation. Submandibular fossa is lacking in

354 much of the specimen; only being evident at the posterior of the rami where it transitions into the

355 shallow pterygoid fossa along the medial surface of the angle ventral to the posterior of the $\mathrm{m} 3$.

356 All cheek teeth are bunodont and brachydont.

Anterodorsally oriented, the incisors of ETMNH 5615 exhibit a subspatulate to

358 subconical morphology with the i3 exhibiting a reduced peg-like condition (Table 4). All

359 incisors are procumbent. Wear is evident on the occlusal surface of the il in the development of

360 a pseudo-cylindrical wear facet comprised of an ellipsoid fossette bound by enamel. The i2 is

361 worn, with the anterior-most portion equal to the surface of the wear facet for the i1. Remaining 
362 portions of the elliptical wear facet exhibit a posterolabial trend. Peg-like i3, only present on the

363 right, appears to exhibit rounding of its occlusal surface. A small diastema - approximately 7

$364 \mathrm{~mm}$ - occurs between the $\mathrm{i} 3$ and anterior boundary of the canine. Canines are typical of

365 tayassuids, with a triangular outline and occlusal wear on the posterior surface.

Triangular in occlusal outline, the p2 of ETMNH 5615 exhibits two roots (Fig. 11).

367 Protoconid, conic in profile, is the primary cusp of the p2 and is well elevated above the talonid

cusp/cuspule. A weak anterior cingulum trends along the anterior surface of the protoconid.

Talonid cusp/cuspule is positioned directly posterolabial of the protoconid on the right $\mathrm{p} 2$. Left

p2 appears to lack this cusp due to damage and/or merger through wear. A weak lingual cingulum trends from the posterolabial edge of the protoconid along the labial and posterior edges of the talonid basin.

Trapezoidal in occlusal outline, the p3 of ETMNH 5615 exhibits four primary cusps and

evidence for two to three roots. Trigonid is comprised of poorly bifurcated protoconid and metaconid that may merge with wear. A strong anterior cingulum is positioned along the anterior base of the trigonid cusps. An accessory cuspule, or posterolabial extension of the metaconid, is evident along the posterior margin of the protoconid and metaconid. Merger of this feature with the metaconid through wear is present in ETMNH 5615. Talonid is comprised of two rounded cusps/cuspules that are separated from the trigonid cusps (and themselves) by weak valleys. A weak labial cingulum extends across the short valley between the protoconid and the hypoconid. Evidence is present for a posterior cingulum but both left and right p3 exhibit an elongate fossette and/or damage along the posterior margin of the tooth. 
385 talonid cusps. Weakly to moderately worn in nature, ETMNH 410 exhibits a moderate anterior

386 cingulum along the base of the trigonid. Anterior cingulum of ETMNH 5615 merges with the

387 trigonid through wear. Metaconid is merging with its posterior extension or accessory cuspule in

388 both ETMNH 410 and ETMNH 5615. Deep valleys separate the trigonid and talonid, with the

389 labial valley exhibiting a moderate cingulum between the posterior edge of the protoconid and

390 the anterior edge of the hypoconid. Entoconulid does not appear to be present in either ETMNH

391410 or ETMNH 5615. Hypoconid exhibits anterolingual extension of its wear facet in ETMNH

392410 toward where the entoconulid would be positioned in a molariform premolar, however, no

393 evidence of a distinct cusp is present. In ETMNH 5615 the hypoconid and entoconid wear to a

394 circular occlusal profile, with centrally positioned circular to ellipsoid fossettes. Hypoconulid

395 remains separate in both specimens being positioned along the posterolingual edge of the

396 hypoconid.

Despite being heavily worn in ETMNH 5615, the $\mathrm{m} 1$ exhibits quadrate, four rooted condition. Enamel is only present along the lingual edge of the right $\mathrm{m} 1$ and along the entire labial edge and lingual edge of the metacone of the left $\mathrm{m} 1$ due to the entoconid being absent. margin of both the right and left $\mathrm{ml}$ 's of ETMNH 5615 exhibit a concave depression that conforms to the posterior margin of the preceding $\mathrm{p} 4$. weak furrow. Protoconid exhibits an ellipsoid fossette with an extension to the paraconule and anterior cingulum. Metaconid also exhibits an ellipsoid fossette bearing an ellipsoid extension into the merged posterior extension or accessory cuspule. Trigonid and talonid are still separated 
408 by a moderate valley that is weak anterolingual of the entoconulid. A weak labial cingulum is 409 present between the protoconid and hypoconid. Hypoconid is merging anterolingually with the 410 entoconulid, as well as posterolingually with the hypoconulid and posterior cingulum. A circular

411 fossette dominates the center of the hypoconid with an ellipsoid extension into the site of the 412 entoconulid. Hypoconulid, despite being worn flat to the posterior cingulum, exhibits an 413 ellipsoid fossette that remains separate from the hypoconid fossette. Entoconid remains separate 414 with an ellipsoid fossette dominating the center of the cusp. surface with the metaconid and entoconid exhibiting less wear. A strong anterior cingulum

417 trends across the anterior of the trigonid cusps. Protoconid exhibits anterolingual merger with 418 the paraconulid and anterior cingulum. Metaconid is merged with its posterolabial extension or 419 accessory cuspule. Deep valleys separate the trigonid and talonid, while a labial cingulum trends 420 between the protoconid and hypoconid. Hypoconulid is merged anterolingually with the 421 entoconulid but remains separate from the hypoconulid. Moreover, the $\mathrm{m} 3$ exhibits a bulbous 422 hypoconulid complex with a single broad and robust cusp posterior to the anteroposteriorly compressed hypoconulid. Left $\mathrm{m} 3$ exhibits merger of the hypoconulid with the heel cusp along 424 the posterolabial edge of the cuspule.

425 Comparisons-Specimens are attributed to Prosthennops serus due to the presence of a robust, 426 bunodont and brachydont dentition. At the generic level, these specimens can be differentiated 427 from Mylohyus based on the presence of submolariform p2's and a post-canine diastema that is 428 less than the length of the cheek tooth row. Moreover, all specimens being assigned to 429 Prosthennops serus exhibit a triangular p2 with a single prominent cusp anterior to the talonid; 430 further distinguishing these specimens from the lophate, subzygodont to zygodont Protherohyus 
431 brachydontus and Platygonus pollenae. Cranial apomorphies specific to Prosthennops serus

432 (e.g. distally angular zygomatic wings, zygoma originating dorsal to premolars (Wright, 1991, 433 1998)) are not evident in the GFS material due to the lack of crania. Partial mandible, ETMNH 5615, is comparable to UF 212306, UF 166243, a cast of the type specimen (AMNH 8511), originally described by Cope (1877), UNSM 76052, UNSM 76054, and UNSM 76059 (Table S1). Symphyses of these specimens exhibit a deep anteroposteriorly trending semi-cylindrical spout-like concavity that opens along the posterior margin of the symphysis. Moreover, each of these specimens' exhibit dentitions that are bunodont and brachydont with a submolariform p2 and p3 and a molariform p4. Dentition of UF 212306 and UF 166243 is less worn compared to ETMNH 5615 (Fig. 11). Continuation of the anterior cingulum along the anterolabial edge of the protoconid into the labial cingulum on the p3 differentiates UF 212306, ETMNH 5615, UF 166243, UNSM 76052, and UNSM 76054. In

443 ETMNH 5615, UF 166243, UNSM 76052, and UNSM 76054 this cingulum terminates along the 444 anterior edge of the protoconid, with an isolated labial cingulum present within the median 445 valley between the protoconid and hypoconid. Labial cingulum trends posteriorly along the 446 labial edge of the hypoconid in UF 166243. A labial cingulum is also observed in the $\mathrm{p} 4$ with 447 ETMNH 5615, UF 212306, UNSM 76052, UNSM 76054, and UNSM 76059 exhibiting a labial 448 cingulum that is restricted within the median valley. Alternatively, UF 166243 exhibits an extension of the cingulum along the labial to posterior margin of the hypoconid of the $\mathrm{p} 4$. None 450 of the observed specimens adequately represent the cusps of the $\mathrm{m} 1$ due to wear or loss through damage. Remaining molars exhibit a similar morphology, with ETMNH 5615 exhibiting more

452 labiolingually broad and robust anterior and posterior cingula of the $\mathrm{m} 2$ and $\mathrm{m} 3$ than UF 212306 , 453 UF/TRO 413, UF 166243, UNSM 76052, UNSM 76054, or UNSM 76059. Both UF 220251 
454 and UF/TRO 413 exhibit m3's that are comparable to ETMNH 5615, UF 212306, UNSM 76052,

455 UNSM 76054, and UNSM 76059 due to the relative morphology of the cusps and the

456 hypoconulid complex being dominated by two to three poorly bifurcated accessory cusps that

457 may merge together through wear into a single prominent cusp. Overall, ETMNH 5615, UF

458 212306, UF220251, and UF/TRO 413 exhibit similar dental and mandibular characteristics to the

459 cast of the type specimen-UF 166243 — and those described in Hesse (1935), Colbert (1938),

460 and Schultz and Martin (1975); however, dental dimensions vary within the sample (Fig. 11).

461 Specimens from the GFS and Tyner Farm Locality are proportionally larger than the material

462 described by Hesse (1935), Colbert (1938), and Schultz and Martin (1975), indicating greater

463 interspecific variation than previously recognized.

\section{DISCUSSION}

465 Previously only known from the Palmetto Fauna of Florida (Wright \& Webb, 1984; Wright, 466 1991, 1998) within the Fort Green Mine, Palmetto Mine, Payne Creek, Saddle Creek Mine, and

467 South Pierce quarries, M. elmorei exhibits a northward expansion into the Appalachian region

468 with the inclusion of GFS material (Fig 1). Although this discovery expands the range of $M$.

469 elmorei, it does not negate the assertion by Webb et al. (2008) that the species is endemic to the

470 southeastern North America. Mylohyus, as a genus, is widespread throughout parts of North

471 America (Wright, 1998). Mylohyus fossilis in particular is prevalent through the Blancan to

472 Rancholabrean of the central and southeastern regions of North America (Kinsey, 1974; Kurten

473 \& Anderson, 1980; Wright, 1991, 1998). Alternatively, another Hemphillian species within the

474 genus, $M$. longirostris, is reported from the John Day region based on a single rami and

475 fragmentary cranial material (Thorpe, 1924; Wright, 1991, 1998). Wright (1998) attributes

476 material collected from the Hemphillian Mixon's Bone Bed local fauna of Florida as being 
477 affiliated to M. longirostris; however, only the locality is designated. No specimen data is

478 reported to verify this record. In sum, the geographic distribution of these species illustrates the

479 potential for a larger distribution for M. elmorei, however, the rarity of the species within given

480 localities can make further range expansions difficult to determine. eastward and northward into the Appalachian Mountain region, making GFS the second easternmost locality from which Prosthennops serus is recognized (Fig. 1). Following Wright (1998), Prosthennops serus - senso stricto - is known from the early Clarendonian of Kansas (Cope, 1877; Wright, 1998), earliest Hemphillian of Oregon (Colbert, 1938), earliest to late early Hemphillian of Nebraska (Hesse, 1935; Schultz \& Martin, 1975), earliest Hemphillian to Blancan of an unnamed unit within Hidalgo, Mexico (Wright, 1998), late early Hemphillian of Alabama (Hulbert \& Whitmore, 2006), and early Hemphillian Tyner Farm locality of Florida (Hulbert et al., 2009a). Material from the late to latest Hemphillian of the Coffee Ranch Fauna of Texas - approximately 6.6 Ma (Passey et al., 2002) - and Ocote Fauna of Mexico are also referred by Wright (1998), however, no catalog numbers are listed resulting in ambiguity regarding whether this refers to new or reassigned material. Other localities listed by Wright (1998) as bearing material comparable to Prosthennops serus are located within the earliest Hemphillian of the Deer Lodge Basin of Montana, late early Hemphillian Higgins Local Fauna of Texas, and late early Hemphillian of the Wray Fauna of Colorado. Webb and Perrigo (1984) also refer a well-worn $\mathrm{m} 3$ as being comparable to the species from the Gracias Fm. of Honduras, however, the worn nature of the tooth and predominant use of anteroposterior and transverse 498 measurements make this identification suspect. 
500 provides further evidence for a forested environment. Additionally, their presence draws further

501 parallels to the Palmetto Fauna. Mylohyus elmorei and Protherohyus brachydontus within the

502 Palmetto Fauna are referred to by Webb et al. (2008) as browse-dominated mixed-feeders.

503 DeSantis and Wallace (2008) report that two of the GFS tayassuid specimens exhibit a C 3

504 dominated dietary profile. Despite the specimens being attributed to M. elmorei and

505 Prosthennops serus not being recovered until after DeSantis and Wallace (2008), a similar

506 browsing diet is suggested for the GFS M. elmorei and Prosthennops serus material based on

507 morphology. Specifically, the presence of a bunodont and brachydont dentition is cited by

508 Hulbert (2001) as an indicator for M. fossilis being a forest species that subsisted on fruit, nuts,

509 and succulents. Additional evidence for this dietary preference in fossil peccaries, including $M$.

510 elmorei, has been reported using stable carbon isotope and dental microwear texture analyses

511 (Yann and DeSantis, 2014; Bradham et al., 2018). Similar parallels are drawn by Woodburne

512 (1968), Kiltie (1981), Sowls (1997) and Wright (1998) based on observations on the populations

513 of modern woodland populations of Pecari (=Dicotyles) tajacu and Tayassu pecari.

514 Additionally, potential dental pathologies (e.g. caries such as those described by Andrews

515 (1973), Coyler (1990), Figueirido et al. (2017), and Wang et al. (2017)) on the m1's of ETMNH

5168046 further suggest a frugivorous or sugar-rich diet that would fit in with the current

517 interpretation of the site being an oak-hickory forest. 
519 (Samuels, Bredehoeft \& Wallace, 2018). This suggestion brings the maximum age of the GFS to

520 be in line with that of the Palmetto Fauna of Florida, which is interpreted to be 5.0-4.5 Ma

521 (Tedford et al., 2004; Webb et al., 2008). Presence of M. elmorei could be used to reinforce the

522 upper age limit of GFS, however, there is a possibility that the GFS represents an earlier or later

523 record for M. elmorei. Moreover, the presence of Prosthennops serus at the GFS cannot be

524 utilized to constrain the age due to the species being known from the latest Clarendonian to

525 earliest Blancan (Wright, 1998). Further verification of material from other sites and radiometric

526 analyses, where permissible, are needed to utilize any of the GFS tayassuids for further

527 constraining the site's biochronology.

\section{CONCLUSIONS}

529 Within the GFS tayassuid material a total of two individuals attributed to M. elmorei and 530 Prosthennops serus, respectively, are recognized through systematic analyses. Accordingly, the

531 known distribution of M. elmorei and Prosthennops serus is expanded north into the

532 Appalachian region; the first reported instance of M. elmorei outside the Palmetto Fauna of

533 Florida. Moreover, the presence of M. elmorei emphasizes further parallels between the

534 Palmetto Fauna and the GFS reinforcing the paleoenvironmental interpretation of the latter and

535 suggesting a greater connectivity between the faunas than previously thought. Indeterminant

536 tayassuid material that cannot be directly assigned to either species is evident within the GFS

537 fauna, however, the limited and fragmentary nature of the remaining tayassuid material prevents

538 the designation of another species at this time. Future work focused on this material, in

539 particular the postcranial material, is necessary to further discern the ecology and morphological 
540 variation of these species both within the GFS and late Hemphillian to early Blancan of North

541 America.

\section{ACKNOWLEDGMENTS}

We thank Jim Mead for comments and suggestions on an earlier version of this

544 manuscript. Moreover, further thanks are due to Sandra Swift for her aid and overall support

545 throughout the project. Additional thanks to Shawn Haugrud, Brian Compton, April Nye, and

546 Anthony Woodward for their assistance in ETSU collections. We thank Dr. Richard Hulbert for

547 providing access to the University of Florida (UF) collections and providing references and

548 feedback related to the collection. Recognition for the photography goes to Sean Moran.

549 Express thanks are also due to Dr. James Farlow and Ronald Richards for providing access and

550 consultation regarding the tayassuid material associated with the Pipe Creek paleosinkhole. We

551 thank Dr. Hugh "Greg” McDonald for his assistance in clarifying morphological nomenclature.

552 Lastly, we thank reviewers for their helpful comments and edits to this manuscript.

\section{REFERENCES}

554 Andrews AH. 1973. Dental caries in an experimental domestic pig. The Veterinary record $55593: 257-258$.

556

557

558

559

560

561

Bradham JL., DeSantis LRG., Jorge MLSP., Keuroghlian A. 2018. Dietary variability of extinct tayassuids and modern white-lipped peccaries (Tayassu pecari) as inferred from dental microwear and stable isotope analysis. Palaeogeography, Palaeoclimatology, Palaeoecology 499:93-101.

Bourque JR., Schubert BW. 2015. Fossil musk turtles (Kinosternidae, Sternotherus) from the late Miocene-early Pliocene (Hemphillian) of Tennessee and Florida. Journal of Vertebrate 
Paleontology 35:1-19. DOI: 10.1080/02724634.2014.885441.

563 Colbert EH. 1938. Pliocene peccaries from the Pacific Coast region of North America. Carnegie

$564 \quad$ Institute of Washington Publication 487:241-269.

565

566

567

568

569

570

571

572

573

574

575

576

577

578

579

580

581

582

Cope ED. 1877. Descriptions of new Vertebrata from the upper Tertiary formations of the West. Proceedings of the American Philosophical Society 17:219-231.

Cope ED. 1889. The Artiodactyla (Continued). The American Naturalist 23:111-136.

Coyler JF. 1990. Colyer's variations and diseases of the teeth of animals, revised edition. Cambridge: Cambridge University Press. DOI: 10.1017/CBO9780511565298.

DeSantis LRG., Wallace SC. 2008. Neogene forests from the Appalachians of Tennessee, USA: Geochemical evidence from fossil mammal teeth. Palaeogeography, Palaeoclimatology, Palaeoecology 266:59-68. DOI: 10.1016/j.palaeo.2008.03.032.

Farlow JO., Sunderman JA., Havens JJ., Swinehart AL., Holman JA., Richards RL., Miller NG., Martin RA., Hunt Jr RM., Storrs GW., Curry BB., Fluegeman RH., Dawson MR., Flint MET. 2001. The Pipe Creek Sinkhole Biota, a diverse Late Tertiary continental fossil assemblage from Grant County, Indiana. American Midland Naturalist 145:367-378.

Figueirido B., Pérez-Ramos A., Schubert BW., Serrano F., Farrell AB., Pastor FJ., Neves AA., Romero A. 2017. Dental caries in the fossil record: a window to the evolution of dietary plasticity in an extinct bear. Scientific Reports 7:1-7. DOI: 10.1038/s41598-017-18116-0.

Gidley JW. 1904. New or little known mammals from the Miocene of South Dakota: American Museum Expedition of 1903. (By WD Matthew and JW Gidley, Part. III, Dicotylidae by JW Gidley). Bulletin of the American Museum of Natural History 20:241-268. 
583 Hesse CJ. 1935. A vertebrate fauna from the type localiity of the Ogallala Formation. University $584 \quad$ of Kansas Science Bulletin 32:79-118.

585 Hulbert RC. 2001. The fossil vertebrates of Florida. Gainesville: University Press of Florida.

586 Hulbert RC., Morgan GS., Kerner A. 2009a. Collared Peccary (Mammalia, Artiodactyla, 587 Tayassuidae, Pecari) from the Late Pleistocene of Florida. Papers on Geology, Vertebrate 588 Paleontology, and Biostratigraphy in Honor of Michael O. Woodburne. Museum of $589 \quad$ Northern Arizona Bulletin 65, Flagstaff, Arizona. 65:543-556.

590 Hulbert RC., Wallace SC., Klippel WE., Parmalee PW. 2009b. Cranial morphology and 591 systematics of an extraordinary sample of the late Neogene dwarf tapir, Tapirus polkensis 592 (Olsen). Journal of Paleontology 83:238-262.

593

594

595 596

Hulbert RC., Whitmore FC. 2006. Late Miocene mammals from the Mauvilla Local Fauna, Alabama. Bulletin of the Florida State Museum 46:1-28.

Kiltie RA. 1981. Stomach contents of rain forest peccaries (Tayassu tajacu and T. pecari). Biotropica 13:234-236.

Kinsey PE. 1974. A New Species of Mylohyus Peccary from the Florida Early Pleistocene. In: Webb SD ed. Pleistocene Mammals of Florida. University Presses of Florida, 158-169.

Kurten B., Anderson E. 1980. Pleistocene mammals of North America. New York: Columbia University Press.

Linnaeus C. 1758. Systema naturae per regna tria naturae: secundum classes, ordines, genera, species, cum characteribus, differentiis, synonymis, locis. Stockholm: Tomus I. L. Salvii.

Liu YSC., Jacques FMB. 2010. Sinomenium macrocarpum sp. nov. (Menispermaceae) from the 
604 Miocene--Pliocene transition of Gray, northeast Tennessee, USA. Review of Palaeobotany $605 \quad$ and Palynology 159:112-122.

606 Mcdonald HG., De Muizon C. 2002. The cranial anatomy of Thalassocnus (Xenarthra, 607 Mammalia), a derived nothrothere from the Neogene of the Pisco Formation (Peru). Journal 608 of Vertebrate Paleontology 22:349-365. DOI: 10.1671/0272609 4634(2002)022[0349:TCAOTX]2.0.CO;2.

610

611

612

613

614

615

616

617

618

619

620

621

622

623

624

De Muizon C., Mcdonald HG., Salas R., Urbina M. 2003. A new early species of the aquatic sloth Thalassocnus (Mammalia, Xenarthra) from the Late Miocene of Peru. Journal of Vertebrate Paleontology 23:886-894. DOI: 10.1671/2361-13.

Ochoa D., Whitelaw M., Liu YSC., Zavada M. 2012. Palynology of Neogene sediments at the Gray Fossil Site, Tennessee, USA: Floristic implications. Review of Palaeobotany and Palynology 184:36-48. DOI: 10.1016/j.revpalbo.2012.03.006.

Owen R. 1848. Description of teeth and portions of jaws of two extinct anthracotherioid quadrupeds (Hyopotamus vectianus and Hyop. bovinus) discovered by the Marchioness of Hastings in the Eocene deposits on the NW coast of the Isle of Wight: with an attempt to develop. Quarterly Journal of the Geological Society of London 4:104-141.

Palmer TS. 1897. Notes on the nomenclature of four genera of tropical American mammals. Proceedings of the Biological Society of Washington 11:173-174.

Parisi Dutra R., de Melo Casali D., Missagia RV., Gasparini GM., Perini FA., Cozzuol MA. 2016. Phylogenetic systematics of peccaries (Tayassuidae: Artiodactyla) and a classification of South American tayassuids. Journal of Mammalian Evolution 24:345-358. 
625 Parmalee PW., Klippel WE., Meylan PA., Holman JA. 2002. A Late Miocene-Early Pliocene 626 population of Trachemys (Testudines: Emydidae) from east Tennessee. Annals of Carnegie $627 \quad$ Museum 71:233-239.

628 Passey BH., Cerling TE., Perkins ME., Voorhies MR., Harris JM., Tucker ST. 2002.

629 Environmental change in the Great Plains: an isotopic record from fossil horses. The 630 Journal of Geology 110:123-140.

631 Prothero DR., Sheets HA. 2013. Peccaries (Mammalia, Artiodactyla, Tayassuidae) from the 632 Miocene-Pliocene Pipe Creek Sinkhole Local Fauna, Indiana. Kirtlandia 58:54-60.

633

634

635

636

637

Samuels JX., Bredehoeft KE., Wallace SC. 2018. A new species of Gulo from the Early Pliocene Gray Fossil Site (Eastern United States); rethinking the evolution of wolverines. PeerJ 6:e4648. DOI: 10.7717/peerj.4648.

Schultz CB., Martin LD. 1975. A new Kimballian peccary from Nebraska. Bulletin of the University of Nebraska State Museum 10:35-46.

Short RA. 2013. A new species of Teleoceras from the Late Miocene Gray Fossil Site, with comparisons to other North American Hemphillian species. Electronic Theses and Dissertations. Paper 1143. https://dc.etsu.edu/etd/1143.

Shunk AJ., Driese SG., Clark GM. 2006. Latest Miocene to earliest Pliocene sedimentation and climate record derived from paleosinkhole fill deposits, Gray Fossil Site, northeastern Tennessee, U.S.A. Palaeogeography, Palaeoclimatology, Palaeoecology 231:265-278. DOI: $10.1016 /$ j.palaeo.2005.08.001.

Shunk AJ., Driese SG., Farlow JO., Zavada MS., Zobaa MK. 2009. Late Neogene paleoclimate 
646

647

648

649

650

651

652

653

654

655

656

657

658

659

660

661

662

663

664

665

666

and paleoenvironment reconstructions from the Pipe Creek Sinkhole, Indiana, USA.

Palaeogeography, Palaeoclimatology, Palaeoecology 274:173-184. DOI:

10.1016/j.palaeo.2009.01.008.

Sisson S., Grossman JD. 1975. The anatomy of the domestic animals. Philadelphia: W.B. Saunders Co.

Sowls LK. 1997. Javelinas and other peccaries: their biology, management, and use. College Station: Texas A\&M University Press.

Tedford RH., Albright III LB., Barnosky AD., Ferrusquia-Villafranca I., Hunt Jr RM., Storer JE., Swisher III CC., Voorhies MR., Webb SD., Whistler DP., others. 2004. Mammalian biochronology of the Arikareean through Hemphillian interval (late Oligocene through early Pliocene epochs). In: Late Cretaceous and Cenozoic mammals of North America: biostratigraphy and geochronology. New York: Columbia University Press, 169-231.

Thorpe MR. 1924. A new species of extinct peccary from Oregon. American Journal of Science 41:393-397. DOI: 10.1017/S1355617712001555.

Von den Driesch A. 1976. A guide to the measurement of animal bones from archaeological sites. Cambridge: Peabody Museum Bulletins, Harvard University.

Wallace SC., Wang X. 2004. Two new carnivores from an unusual late Tertiary forest biota in eastern North America. Nature 431:556-559.

Wang X., Rybczynski N., Harington CR., White SC., Tedford RH. 2017. A basal ursine bear (Protarctos abstrusus) from the Pliocene High Arctic reveals Eurasian affinities and a diet rich in fermentable sugars. Scientific Reports 7:17722. DOI: 10.1038/s41598-017-17657-8. 
667 Webb SD., Hulbert Jr. RC., Morgan GS., Evans HF. 2008. Terrestrial mammals of the Palmetto

668 Fauna (early Pliocene, latest Hemphillian) from the central Florida phosphate district. $669 \quad$ Natural History Museum Los Angeles County Science Series 41:293-312.

670 Webb SD., Perrigo SC. 1984. Late Cenozoic Vertebrates from Honduras and El Salvador. $671 \quad$ Journal of Vertebrate Paleontology 4:237-254.

672 White TE. 1942. Additions to the fauna of the Florida phosphates. In: Proceedings of the New 673 England Zoology Club. 87-91.

674 Whitelaw JL., Mickus K., Whitelaw MJ., Nave J. 2008. High-resolution gravity study of the 675 Gray Fossil Site. Geophysics 73:25-32.

676 Woodburne MO. 1968. The cranial myology and osteology of Dicotyles tajacu, the collared 677 peccary, and its bearing on classification. Memoirs of the Southern California Academy of $678 \quad$ Sciences $7: 1-48$.

679 Wright DB. 1989. Phylogenetic relationships of Catagonus wageni: sister taxa from the Tertiary 680 of North America. Advances in Neotropical Mammalogy:281-308. DOI: $681 \quad 10.1017 / \mathrm{S} 1355617712001555$.

682 Wright DB. 1991. Cranial morphology, systematics, and evolution of neogene Tayassuidae 683 (Mammalia). D. Phil. Thesis, University of Massachusetts.

684 Wright DB. 1998. Tayassuidae. Evolution of tertiary mammals of North America 1:389-401.

685 Wright DB., Webb SD. 1984. Primitive Mylohyus (Artiodactyla: Tayassuidae) from the late 686 Hemphillian Bone Valley of Florida. Journal of Vertebrate Paleontology 3:152-159.

687 Yann LT., DeSantis LRG. 2014. Effects of Pleistocene climates on local environments and 
688 dietary behavior of mammals in Florida. Palaeogeography, Palaeoclimatology, and 689 Palaeoecology 414:370-381. 


\section{Table 1 (on next page)}

Measurements $(\mathrm{mm})$ of the upper dentition and cranium of Mylohyus elmorei.

Approximate measurements are marked by $(*)$. 


\begin{tabular}{|c|c|c|c|c|c|c|c|c|c|c|c|c|c|c|c|}
\hline & \multirow[b]{2}{*}{$\mathrm{N}$} & \multirow[b]{2}{*}{$\bar{X}$} & & & & \multirow[b]{2}{*}{$\sigma^{2}$} & \multirow[b]{2}{*}{$\sigma$} & \multicolumn{3}{|c|}{$\begin{array}{c}\text { ETMNH } \\
8046 \\
\end{array}$} & \multicolumn{3}{|c|}{$\begin{array}{c}\text { UF } \\
12265 \\
\end{array}$} & \multirow{2}{*}{$\begin{array}{c}\text { UF } \\
203540\end{array}$} & \multirow{2}{*}{$\begin{array}{c}\text { UF/TRC } \\
440\end{array}$} \\
\hline & & & \multicolumn{3}{|c|}{ Range } & & & Left & Right & Average & Left & Right & Average & & \\
\hline Length P2-M3 & 2 & 96.45 & 94.91 & - & 98.00 & 2.38 & 1.54 & 97.68 & 98.31 & 98.00 & & 94.91 & & & \\
\hline Length P2-P4 & 2 & 37.40 & 37.35 & - & 37.46 & 0.00 & 0.06 & 36.78 & 37.91 & 37.35 & & 37.46 & & & \\
\hline Length M1-M3 & 2 & 59.20 & 57.20 & - & 61.20 & 4.01 & 2.00 & 61.27 & 61.13 & 61.20 & & 57.20 & & & \\
\hline Post Canine Diastema & 2 & 101.59 & 95.68 & - & 107.51 & 34.95 & 5.91 & 107.51 & & & & $95.68^{*}$ & & & \\
\hline $\begin{array}{l}\text { \% Length of PCD/ Length } \\
\text { P2-M3 }\end{array}$ & 2 & 105 & 101 & - & 110 & 0.00 & 5 & 110 & & & & 101 & & & \\
\hline Height of Canine Buttress & 1 & 51.21 & & & & & & 51.21 & & & & & & & \\
\hline
\end{tabular}

\begin{tabular}{|c|c|c|c|c|c|c|c|c|c|c|c|c|c|c|c|c|}
\hline \multirow[t]{2}{*}{ Canine } & APA & 1 & 22.52 & & & & & & \multirow{2}{*}{\multicolumn{3}{|c|}{$\begin{array}{l}22.52 \\
15.60\end{array}$}} & & & & & \\
\hline & Transverse & 1 & 15.60 & & & & & & & & & & & & & \\
\hline \multirow[t]{3}{*}{$\mathrm{P} 2$} & APO & 2 & 10.34 & 10.31 & \multirow{3}{*}{$\begin{array}{l}- \\
- \\
-\end{array}$} & 10.36 & 0.00 & 0.02 & 10.37 & 10.25 & 10.31 & \multicolumn{3}{|c|}{10.36} & & \\
\hline & AT & 2 & 9.50 & 9.32 & & 9.69 & 0.03 & 0.19 & 9.69 & 9.69 & 9.69 & \multicolumn{3}{|c|}{9.32} & & \\
\hline & PT & 2 & 9.47 & 9.32 & & 9.63 & 0.02 & 0.15 & 9.67 & 9.58 & 9.63 & & 9.32 & & & \\
\hline \multirow[t]{3}{*}{ P3 } & $\mathrm{APO}$ & 2 & 12.44 & 12.36 & \multirow{3}{*}{$\begin{array}{l}- \\
- \\
-\end{array}$} & 12.51 & 0.01 & 0.08 & 12.49 & 12.54 & 12.51 & \multicolumn{3}{|c|}{12.36} & & \\
\hline & AT & 2 & 11.39 & 11.36 & & 11.42 & 0.00 & 0.03 & 11.39 & 11.45 & 11.42 & & 11.36 & & & \\
\hline & PT & 2 & 12.24 & 12.20 & & 12.28 & 0.00 & 0.04 & 12.09 & 12.31 & 12.20 & & 12.28 & & & \\
\hline \multirow[t]{3}{*}{$\mathrm{P} 4$} & APO & 2 & 14.31 & 14.25 & \multirow{3}{*}{$\begin{array}{l}- \\
- \\
-\end{array}$} & 14.38 & 0.00 & 0.07 & 14.28 & 14.48 & 14.38 & & 14.25 & & & \\
\hline & AT & 2 & 12.69 & 12.22 & & 13.17 & 0.23 & 0.48 & 12.01 & 12.42 & 12.22 & & 13.17 & & & \\
\hline & PT & 2 & 14.26 & 13.98 & & 14.54 & 0.08 & 0.28 & 13.68 & 14.29 & 13.98 & & 14.54 & & & \\
\hline \multirow[t]{3}{*}{ M1 } & APO & 2 & 17.63 & 17.09 & \multirow{3}{*}{$\begin{array}{l}- \\
- \\
-\end{array}$} & 18.17 & 0.29 & 0.54 & 18.33 & 18.00 & 18.17 & & 17.09 & & & \\
\hline & AT & 2 & 16.16 & 16.11 & & 16.20 & 0.00 & 0.05 & 16.09 & 16.13 & 16.11 & & 16.20 & & & \\
\hline & PT & 2 & 16.38 & 16.33 & & 16.43 & 0.00 & 0.05 & 16.44 & 16.41 & 16.43 & & 16.33 & & & \\
\hline \multirow[t]{3}{*}{ M2 } & $\mathrm{APO}$ & 2 & 19.33 & 19.07 & \multirow{3}{*}{$\begin{array}{l}- \\
- \\
- \\
\end{array}$} & 19.58 & 0.07 & 0.26 & 19.62 & 19.54 & 19.58 & 19.16 & 18.98 & 19.07 & & \\
\hline & AT & 2 & 17.57 & 17.30 & & 17.84 & 0.07 & 0.27 & 17.88 & 17.81 & 17.84 & 17.23 & 17.38 & 17.30 & & \\
\hline & PT & 2 & 16.84 & 16.14 & & 17.55 & 0.50 & 0.71 & 17.66 & 17.44 & 17.55 & 16.02 & 16.29 & 16.14 & & \\
\hline \multirow[t]{4}{*}{ M3 } & $\mathrm{APO}$ & 4 & 22.57 & 21.29 & \multirow{4}{*}{$\begin{array}{l}- \\
- \\
- \\
-\end{array}$} & 23.36 & 0.69 & 0.83 & 23.57 & 23.14 & 23.36 & 21.33 & 21.27 & 21.29 & 22.36 & 23.26 \\
\hline & AT & 4 & 17.18 & 15.59 & & 18.79 & 1.35 & 1.16 & 16.91 & 16.66 & 16.78 & 15.53 & 15.65 & 15.59 & 17.55 & 18.79 \\
\hline & PT & 4 & 13.76 & 12.34 & & 14.91 & 1.33 & 1.16 & 14.97 & 14.81 & 14.89 & 12.35 & 12.34 & 12.34 & 12.91 & 14.91 \\
\hline & HT & 2 & 9.19 & 8.98 & & 9.40 & 0.04 & 0.21 & 9.29 & 9.51 & 9.40 & 8.86 & 9.09 & 8.98 & & \\
\hline
\end{tabular}

1 


\section{Table 2 (on next page)}

Measurements $(\mathrm{mm})$ of the lower dentition and mandible of Mylohyus elmorei.

Approximate measurements are marked by $(*)$ whereas incomplete measurements, due to the posterior portion of enamel being absent, are marked by $(+)$. 


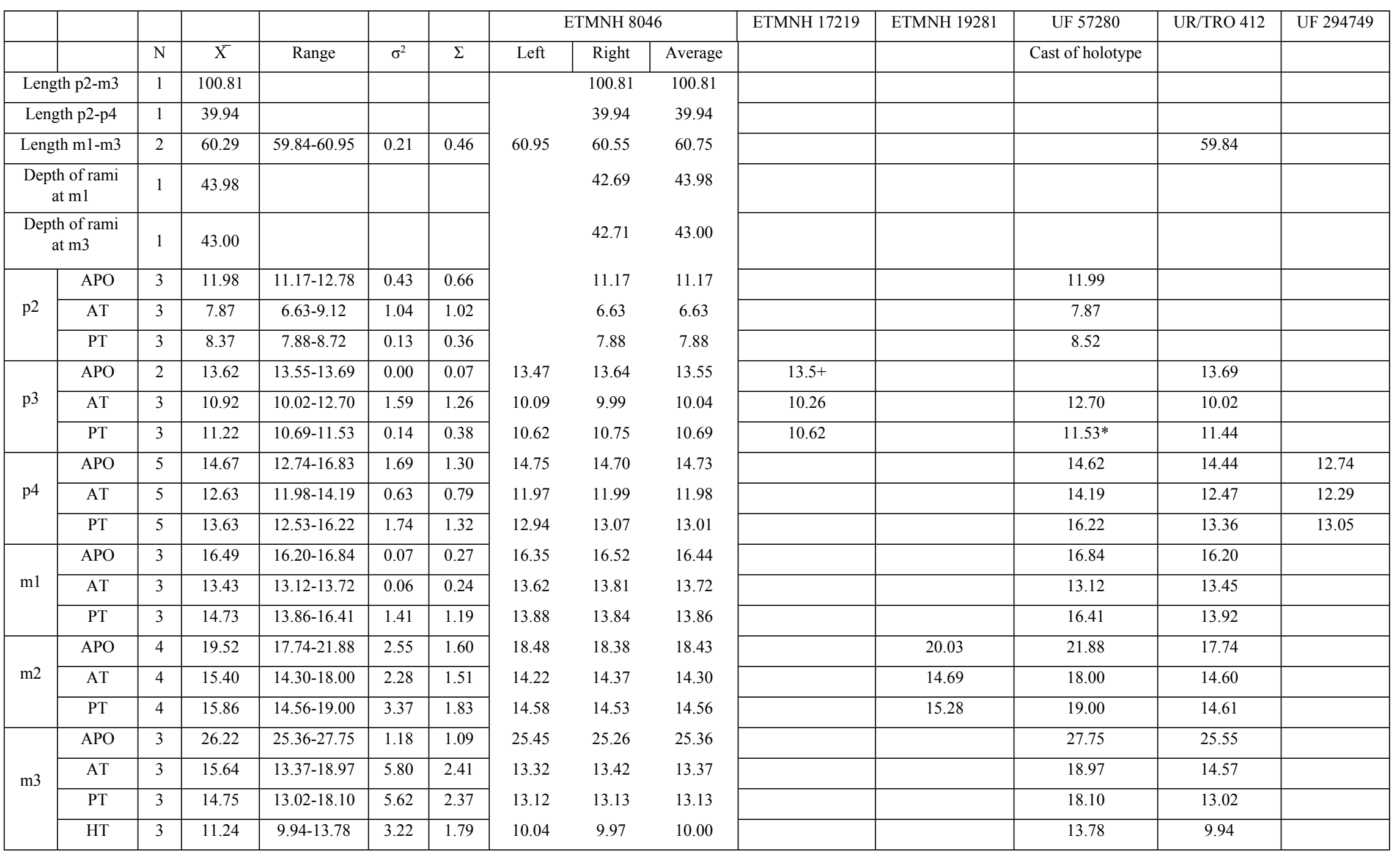


Table 3(on next page)

Measurements $(\mathrm{mm})$ of the lower dentition and mandible of Prosthennops serus.

Approximate measurements are marked by $(*)$. Additional measurement data is taken from (T) Schultz and Martin (1975), (H) Hesse (1935), and (C) Colbert (1938). 


\begin{tabular}{|c|c|c|c|c|c|c|c|c|c|c|c|c|c|c|c|c|}
\hline & & & & & & & & \multicolumn{3}{|c|}{ ETMNH 5615} & \multirow{2}{*}{$\begin{array}{c}\text { UF } 166243 \\
\text { Type Cast } \\
\text { (AMNH8511) }\end{array}$} & UF 212306 & $\begin{array}{l}\text { UNSM } \\
76052^{\mathrm{T}}\end{array}$ & $\begin{array}{l}\text { UNSM } \\
76504^{\mathrm{T}}\end{array}$ & $\begin{array}{l}\text { KUMP } \\
3755^{\mathrm{H}}\end{array}$ & \multirow{2}{*}{$\begin{array}{l}\text { C.I.T } \\
610^{\mathrm{C}}\end{array}$} \\
\hline & $\mathrm{N}$ & $\bar{X}$ & \multicolumn{3}{|c|}{ Range } & $\sigma^{2}$ & $\sigma$ & Left & Right & Average & & & & & & \\
\hline Length $\mathrm{p} 2-\mathrm{m} 3$ & 5 & 97.71 & 91.60 & - & $\begin{array}{c}103.0 \\
6\end{array}$ & 22.86 & 4.78 & $\begin{array}{c}101.9 \\
5\end{array}$ & $\begin{array}{c}104.1 \\
6\end{array}$ & 103.06 & & $102.41^{*}$ & 91.60 & 92.70 & 98.80 & \\
\hline Length $\mathrm{p} 2-\mathrm{p} 4$ & 7 & 38.23 & 36.00 & - & 40.27 & 1.95 & 1.40 & 37.39 & 39.15 & 38.27 & 38.41 & 40.27 & 36.00 & 36.50 & 39.20 & 39.00 \\
\hline Length $\mathrm{m} 1-\mathrm{m} 3$ & 5 & 59.42 & 53.50 & - & 15.98 & 4.00 & 4.16 & 64.22 & 65.18 & 64.70 & & 62.50 & 53.50 & 56.70 & 59.70 & \\
\hline Postcanine Diastema & 6 & 54.87 & 49.90 & - & 62.40 & 28.33 & 5.32 & 61.17 & 63.62 & 62.40 & & $62.04 *$ & 51.50 & 49.90 & 53.40 & 50.00 \\
\hline $\begin{array}{c}\text { \% Length of } \\
\text { PCD/Length } \mathrm{p} 2-\mathrm{m} 3\end{array}$ & 1 & 0.605 & 0.60 & - & 0.61 & 0.00 & 0.00 & & & 0.61 & & 0.60 & & & & \\
\hline Precanine Diastema & 3 & 6.75 & 6.26 & - & 7.50 & 0.29 & 0.54 & 6.01 & 6.51 & 6.26 & & & 7.50 & 6.50 & & \\
\hline $\begin{array}{l}\text { Length Mandibular } \\
\text { symphysis }\end{array}$ & 3 & 86.14 & 82.00 & - & 90.28 & 17.13 & 4.14 & & 92.33 & & & 90.28 & & & & 82.00 \\
\hline $\begin{array}{l}\text { Distance between p2 } \\
\text { and symphysis }\end{array}$ & 1 & & & & & & & & 10.66 & & & & & & & \\
\hline Depth of rami at $\mathrm{m} 3$ & 1 & 39.22 & & & & & & & & & & 39.22 & & & & \\
\hline Depth of rami at $\mathrm{m} 1$ & 3 & 45.79 & 42.27 & - & 50.02 & 10.25 & 3.20 & 48.72 & 51.32 & 50.02 & & 42.27 & 45.10 & & & \\
\hline Width of rami at m3 & 1 & 24.91 & & & & & & & & & & 24.91 & & & & \\
\hline
\end{tabular}


Table 4(on next page)

Measurements $(\mathrm{mm})$ of the lower dentition and mandible of Prosthennops serus.

Approximate measurements are marked by $(*)$. Additional measurement data is taken from (T) Schultz and Martin (1975), (H) Hesse (1935), and (C) Colbert (1938). 


\begin{tabular}{|c|c|c|c|c|c|c|c|c|c|c|c|c|c|}
\hline & & & & & & & & & \multicolumn{3}{|c|}{ ETMNH 5615} & \multirow[t]{2}{*}{ ETMNH 410} & \multirow{2}{*}{$\begin{array}{c}\text { UF } 166243 \\
\text { Type Cast }\end{array}$} \\
\hline & & & & & & & & & & & & & \\
\hline & & $\mathrm{N}$ & $\bar{X}$ & \multicolumn{3}{|c|}{ Range } & $\sigma^{2}$ & $\sigma$ & Left & Right & Average & & (AMNH8511) \\
\hline \multirow{3}{*}{ i1 } & APO & 1 & 8.40 & & & & 0.00 & 0.00 & 8.37 & 8.43 & 8.40 & & \\
\hline & AT & 2 & 5.90 & 4.50 & - & 7.30 & 1.96 & 1.40 & 7.06 & 7.55 & 7.30 & & \\
\hline & $\mathrm{PT}$ & 0 & & & & & & & & & & & \\
\hline \multirow{3}{*}{ i2 } & APO & 3 & 9.94 & 5.41 & - & 12.70 & 10.42 & 3.23 & & 5.41 & 5.41 & & \\
\hline & AT & 4 & 6.59 & 5.00 & - & 8.56 & 1.80 & 1.34 & 8.41 & 8.71 & 8.56 & & \\
\hline & PT & 0 & & & & & & & & & & & \\
\hline \multirow{3}{*}{ i3 } & $\mathrm{APO}$ & 2 & 5.11 & 4.70 & - & 5.51 & 0.16 & 0.40 & & 5.51 & 5.51 & & \\
\hline & AT & 3 & 3.19 & 2.50 & - & 4.47 & 0.82 & 0.90 & & 4.47 & 4.47 & & \\
\hline & PT & 0 & & & & & & & & & & & \\
\hline \multirow[t]{2}{*}{ Canine } & APA & 5 & 16.33 & 13.74 & - & 18.40 & 3.11 & 1.76 & 13.7 & & 13.74 & & \\
\hline & Transvers & 4 & 13.21 & 12.24 & - & 14.60 & 0.86 & 0.93 & 11.9 & 12.57 & 12.24 & & \\
\hline \multirow{3}{*}{$\mathrm{p} 2$} & $\mathrm{APO}$ & 7 & 10.79 & 9.92 & - & 11.25 & 0.20 & 0.45 & 9.79 & 10.06 & 9.92 & & 10.93 \\
\hline & AT & 6 & 6.93 & 6.39 & - & 7.60 & 0.17 & 0.41 & 6.31 & 6.46 & 6.39 & & 6.54 \\
\hline & PT & 3 & 7.25 & 7.16 & - & 7.33 & 0.01 & 0.07 & 7.19 & 7.37 & 7.28 & & 7.16 \\
\hline \multirow{3}{*}{ p3 } & APO & 7 & 12.49 & 11.80 & - & 13.00 & 0.12 & 0.35 & 12.7 & 12.53 & 12.65 & & 12.48 \\
\hline & AT & 6 & 9.34 & 9.00 & - & 9.70 & 0.06 & 0.25 & 9.01 & 9.26 & 9.14 & & 9.22 \\
\hline & PT & 3 & 9.41 & 9.31 & - & 9.61 & 0.02 & 0.14 & 9.48 & 9.73 & 9.61 & & 9.33 \\
\hline \multirow{3}{*}{$\mathrm{p} 4$} & APO & 8 & 15.08 & 13.20 & - & 17.36 & 1.36 & 1.16 & 15.7 & 16.14 & 15.94 & 17.36 & 15.00 \\
\hline & AT & 7 & 11.97 & 11.07 & - & 12.64 & 0.21 & 0.46 & 11.5 & 12.00 & 11.78 & 11.07 & 11.86 \\
\hline & PT & 4 & 13.10 & 12.40 & - & 13.85 & 0.30 & 0.55 & 13.1 & 13.55 & 13.36 & 12.78 & 12.40 \\
\hline \multirow{3}{*}{$\mathrm{m} 1$} & APO & 7 & 14.83 & 13.70 & - & 15.98 & 0.56 & 0.75 & 14.9 & 14.98 & 14.96 & & 15.38 \\
\hline & AT & 6 & 12.61 & 12.00 & - & 13.20 & 0.19 & 0.43 & 12.9 & 12.78 & 12.87 & & 12.10 \\
\hline & PT & 3 & 13.04 & 12.19 & - & 13.96 & 0.53 & 0.73 & & 12.97 & 12.97 & & 12.19 \\
\hline \multirow{3}{*}{$\mathrm{m} 2$} & APO & 8 & 18.82 & 16.80 & - & 20.77 & 1.35 & 1.16 & 20.5 & 21.02 & 20.77 & & 19.71 \\
\hline & AT & 7 & 14.98 & 14.00 & - & 16.00 & 0.46 & 0.68 & 16.0 & 15.99 & 16.00 & & 15.51 \\
\hline & PT & 4 & 15.84 & 15.42 & - & 16.40 & 0.12 & 0.35 & 16.2 & 16.54 & 16.40 & & 15.42 \\
\hline \multirow{4}{*}{$\mathrm{m} 3$} & APO & 7 & 27.61 & 24.50 & - & 32.26 & 5.92 & 2.43 & 29.4 & 29.77 & 29.63 & & \\
\hline & AT & 7 & 16.14 & 14.90 & - & 18.52 & 1.32 & 1.15 & 16.6 & 16.73 & 16.67 & & 15.51 \\
\hline & PT & 5 & 16.09 & 14.86 & - & 17.60 & 0.95 & 0.97 & 16.4 & 16.77 & 16.58 & & 14.86 \\
\hline & HT & 4 & 12.61 & 12.29 & - & 13.14 & 0.10 & 0.32 & 12.5 & 12.53 & 12.54 & & \\
\hline
\end{tabular}

1 


\begin{tabular}{|c|c|c|c|c|c|c|c|c|}
\hline & & UF 220251 & UF 212306 & UF/TRO 413 & UNSM $76052^{\mathrm{T}}$ & UNSM $76504^{\mathrm{T}}$ & KUMP $3755^{\mathrm{H}}$ & C.I.T $610^{C}$ \\
\hline \multirow{3}{*}{ i1 } & APO & & & & & & & \\
\hline & AT & & & & & & & 4.50 \\
\hline & PT & & & & & & & \\
\hline \multirow{3}{*}{ i2 } & APO & & & & 12.70 & 11.70 & & \\
\hline & $\mathrm{AT}$ & & & & 7.00 & 5.80 & & 5.00 \\
\hline & PT & & & & & & & \\
\hline \multirow{3}{*}{ i3 } & $\mathrm{APO}$ & & & & & 4.70 & & \\
\hline & AT & & & & & 2.60 & & 2.50 \\
\hline & PT & & & & & & & \\
\hline \multirow[t]{2}{*}{ Canine } & APA & & & & $18.40^{*}$ & 16.50 & 18.00 & 15.00 \\
\hline & Transverse & & & & $14.60^{*}$ & 12.50 & & 13.50 \\
\hline \multirow{3}{*}{$\mathrm{p} 2$} & APO & & 11.25 & & 11.00 & 10.30 & 11.10 & 11.00 \\
\hline & AT & & 7.26 & & 7.60 & 6.80 & & 7.00 \\
\hline & PT & & 7.33 & & & & & \\
\hline \multirow{3}{*}{ p3 } & $\mathrm{APO}$ & & 13.00 & & 11.80 & 12.70 & 12.30 & 12.50 \\
\hline & AT & & 9.39 & & 9.70 & 9.60 & & 9.00 \\
\hline & PT & & 9.31 & & & & & \\
\hline \multirow{3}{*}{$\mathrm{p} 4$} & $\mathrm{APO}$ & & $15.62 *$ & & 13.20 & 14.70 & 14.30 & 14.50 \\
\hline & $\mathrm{AT}$ & & 12.64 & & 12.40 & 12.00 & & 12.00 \\
\hline & PT & & 13.85 & & & & & \\
\hline \multirow{3}{*}{$\mathrm{m} 1$} & $\mathrm{APO}$ & & $15.98^{*}$ & & 15.30 & 13.70 & 14.00 & 14.50 \\
\hline & AT & & 12.89 & & 13.20 & $12.60^{*}$ & & 12.00 \\
\hline & PT & & 13.96 & & & & & \\
\hline \multirow{3}{*}{$\mathrm{m} 2$} & $\mathrm{APO}$ & & 19.23 & 18.73 & 16.80 & 18.60 & 19.20 & 17.50 \\
\hline & $\mathrm{AT}$ & & 14.84 & 15.58 & 14.40 & 14.50 & & 14.00 \\
\hline & PT & & 15.74 & 15.80 & & & & \\
\hline \multirow{4}{*}{$\mathrm{m} 3$} & $\mathrm{APO}$ & 32.26 & 28.14 & 26.57 & 24.50 & 25.80 & 26.40 & \\
\hline & AT & 18.52 & 16.32 & 16.03 & 14.90 & 15.00 & & \\
\hline & PT & 17.60 & 16.17 & 15.25 & & & & \\
\hline & HT & 13.14 & 12.48 & 12.29 & & & & \\
\hline
\end{tabular}

6 


\section{Figure 1}

Eastern to southeast United States (US) showing locations of the Hemphillian sites bearing peccary material $(A)$.

The Gray Fossil Site (top right) is located in north-central Washington County (B), TN at $36.5^{\circ} \mathrm{N}$ and $82.5^{\circ} \mathrm{W}$. Mylohyus elmorei is previously only known from various localities within the Phosphate Mines (grey) of the Palmetto Fauna (bottom right) (C) (Wright and Webb, 1984; Wright, 1991, 1998). Wright (1998) reports material with affinity to Mylohyus longirostris from the Mixon's Bone Bed local fauna of northern Florida; however, no specimens are directly listed to verify this claim. Prosthennops serus is identified within the Mauville Fauna of southern Alabama (Hulbert and Whitemore, 2006) and the Tyner Farm locality of northern Florida (Hulbert et al. 2009a). Protherohyus brachydontus (=Catagonus brachydontus), despite being widespread in the western US and Mexico, is currently only recognized in the Palmetto Fauna (Wright 1989, 1991, 1998) and the Pipe Creek paleosinkhole of Indiana (Prothero and Sheets, 2013) in the eastern US. 


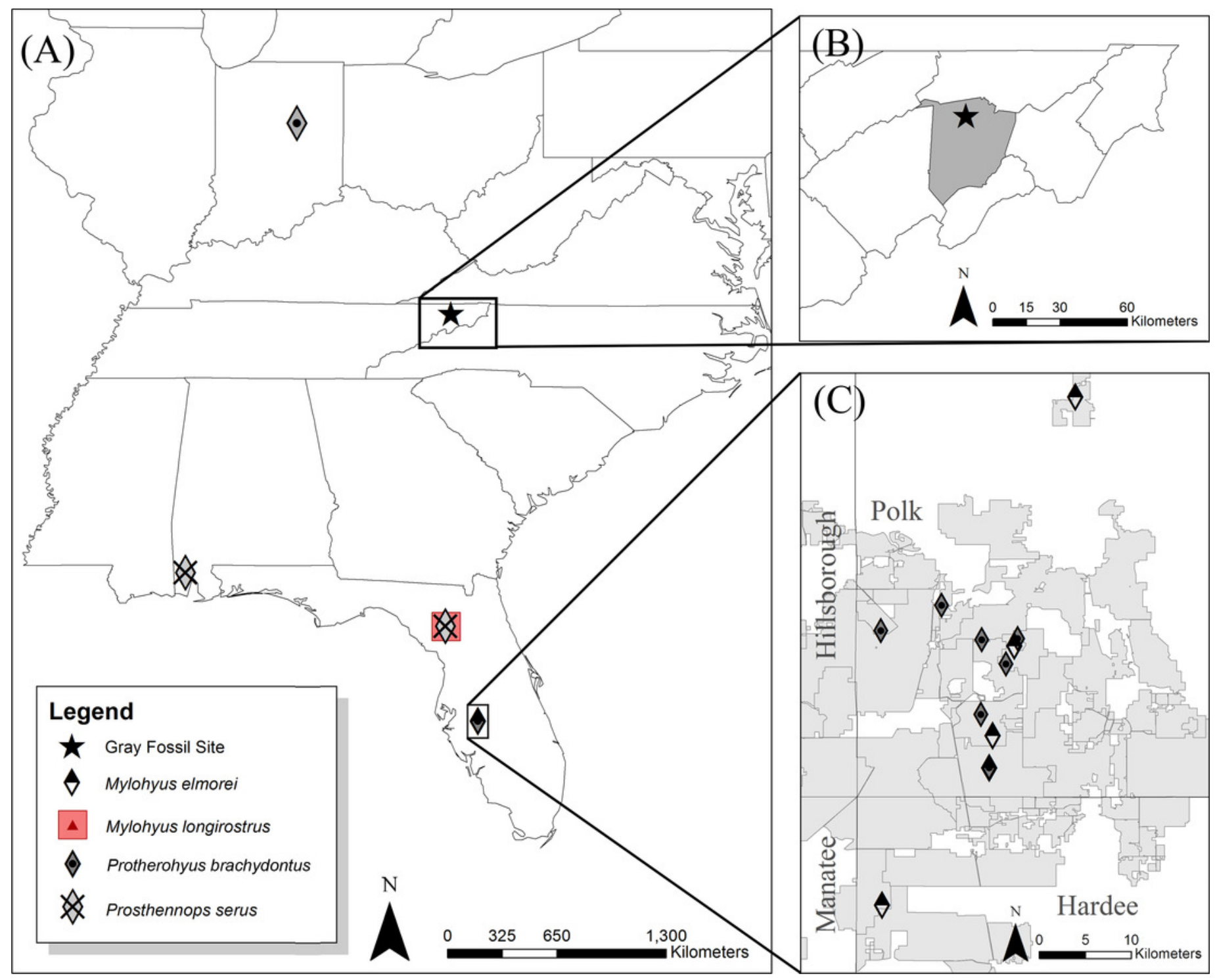


Figure 2

Measurements for tayassuid cranial ( $A$ and $B$ ) and mandibular (C and D) material (ETVP 17584, an adult Pecari tajacu).

Measurements are modified from Von den Driesh (1976) with the abbreviation PCD representing postcanine diastema. 


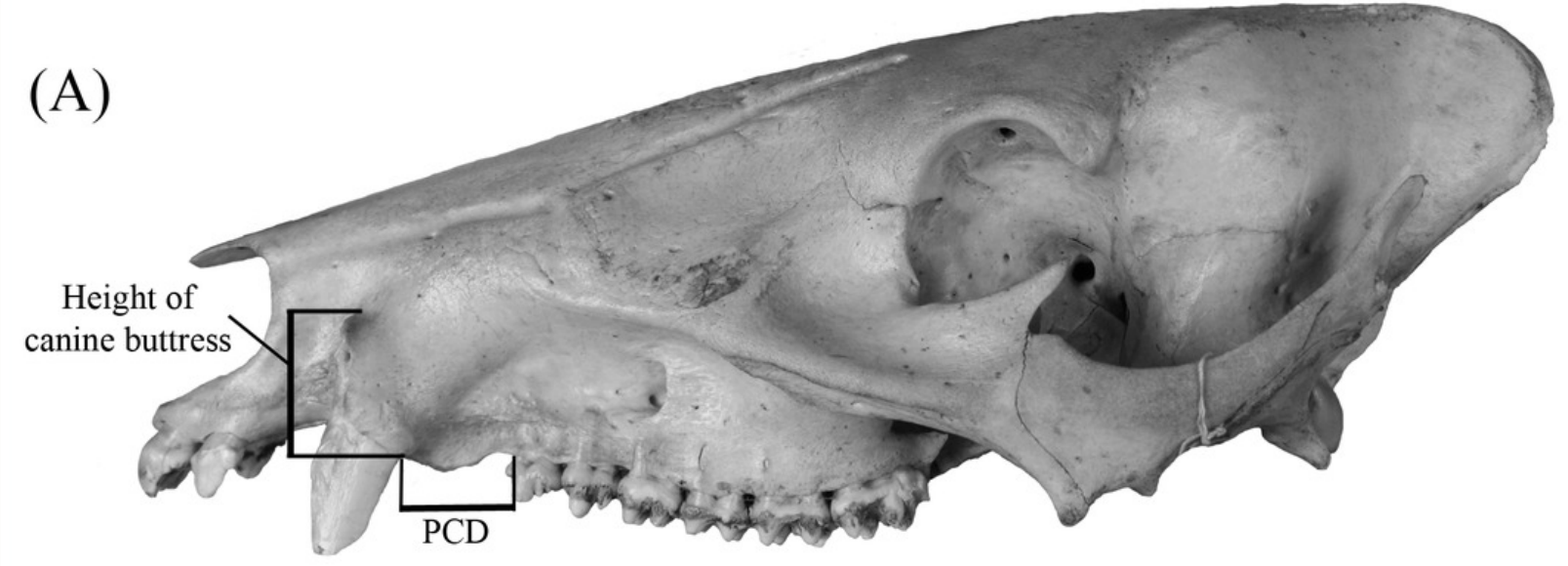

(B)

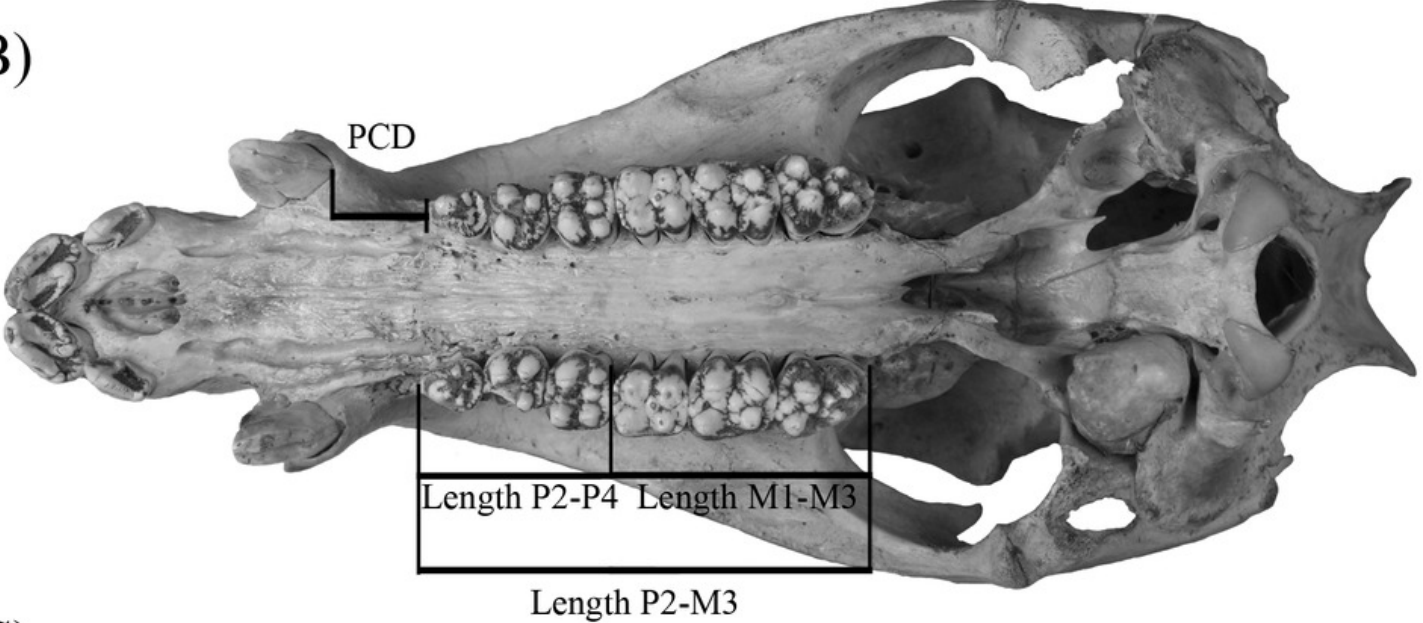

(C)

Length P2-M3

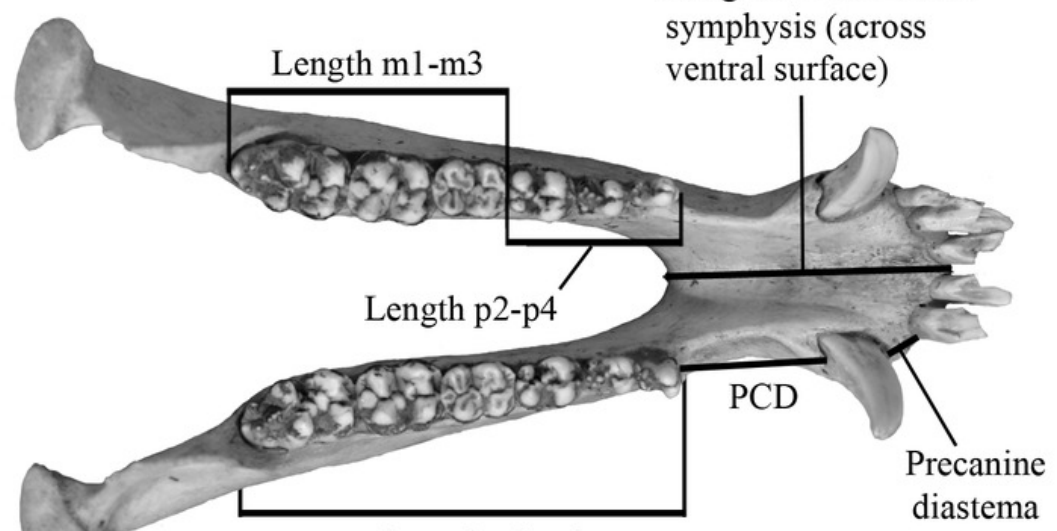

(D)

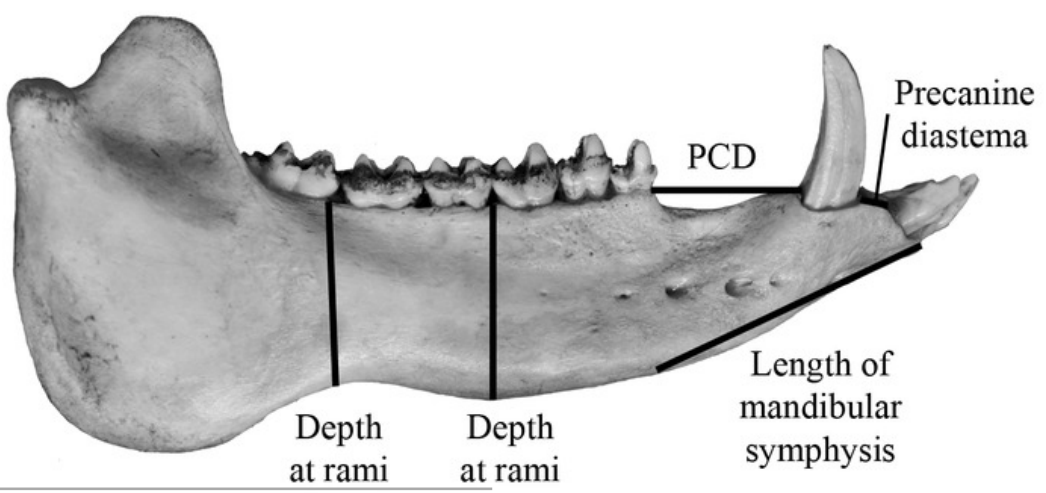




\section{Figure 3}

Dental measurements for both upper and lower dentition (A) follow Wright $(1984,1991)$ with the addition the transverse measurement across the hypoconule/hypoconulid complex.

Abbreviations: $\mathbf{A P O}=$ Greatest anteroposterior length taken along the midline of the occlusal surface of the tooth; $\mathbf{A T}=$ Greatest transverse width of the trigon/trigonid cusps; $\mathbf{P T}=$ Greatest transverse width of the talon/talonid cusps; $\mathbf{H T}=$ Greatest transverse width of the hypoconulid complex. Dental nomenclature (B-E) is modified from Wright $(1989,1991,1998)$ in regards to the posterior heel of upper and lower m3. This accessory cusp-bearing, posteriorly-oriented extension of the M3 and m3's talon/talonid is not referred to in a unified manner within the literature but is typically referred to as the "posterior lobe", "posterior heel", or "heel" (Matthew, 1924; Kinsey, 1974; Schultz \& Martin, 1975; Dalquest \& Mooser, 1980; Wright \& Webb, 1984; Wright, 1989, 1991). Despite indicating a general location on the $M 3 / m 3$, these terms are undescriptive as they do little to describe the composition of the feature, which bears the hypoconule/hypoconulid and a variable number of accessory cusps. Consequently, the terms hypoconule complex and hypoconulid complex are used herein to better describe both the placement and composition of this feature on the upper and lower dentition, respectively. General morphology of the hypoconulid complex is provided (D) for Prosthennops serus (left) and Mylohus elmorei (right), however, it should be indicated that there is notable inter- and intraspecific variation in the number of accessory cuspules on the hypoconulid complex. 

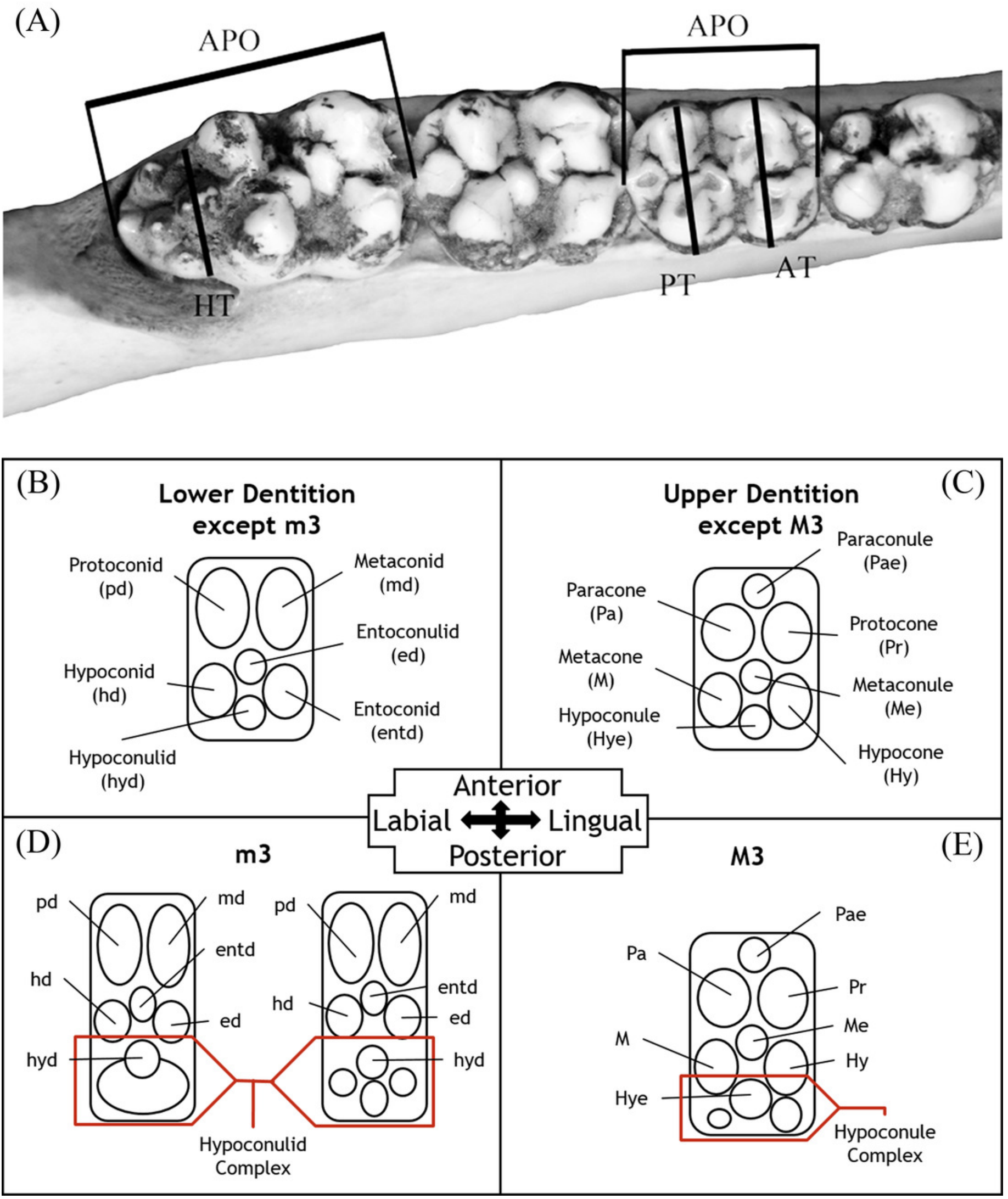


\section{Figure 4}

Gray Fossil Site tayassuid material assigned to Mylohyus elmorei, ETMNH 8046.

This partial cranium exhibits an intact left canine alveolus and right and left P2-M3. Views: A) Lateral; B) occlusal; C) medial. Image is in grayscale to prevent morphologies from being obscured due to coloration. 


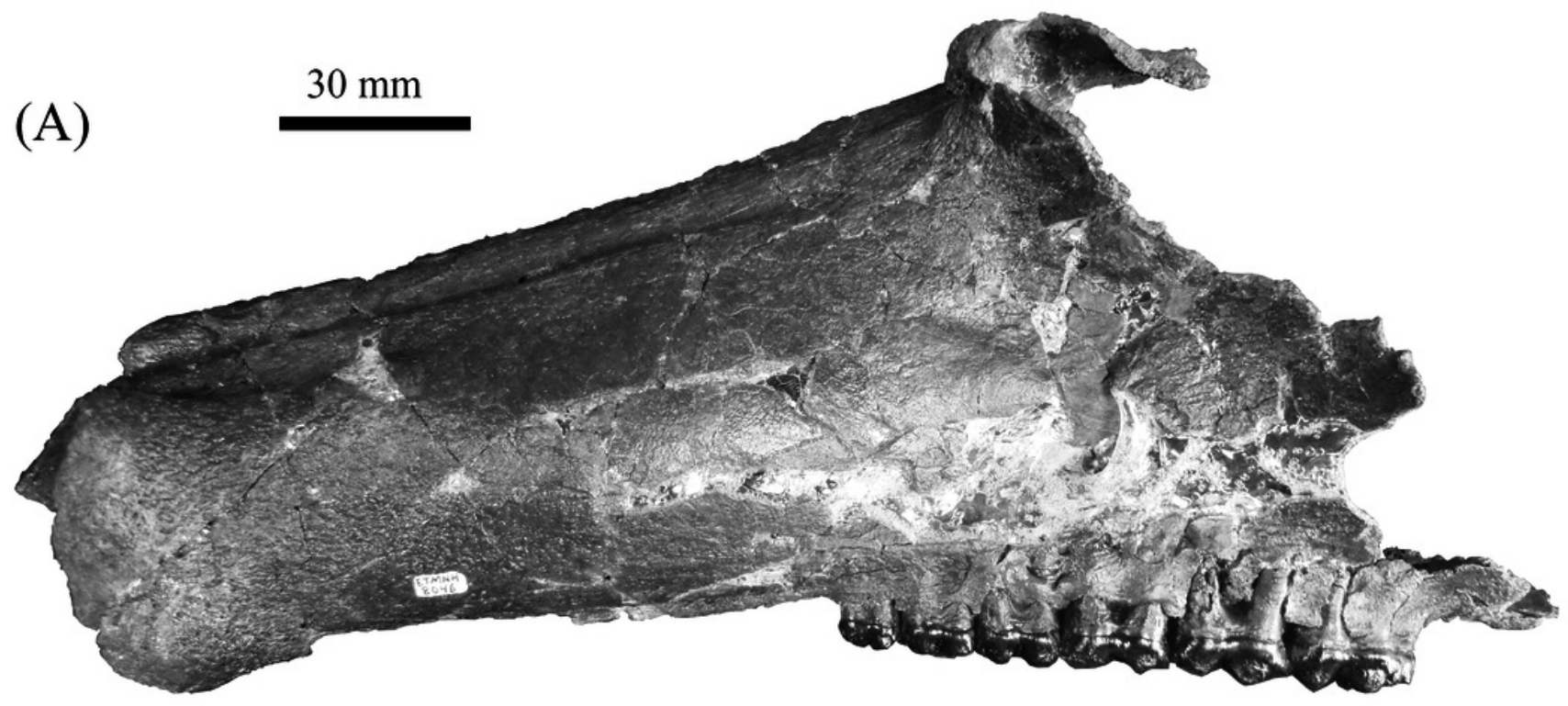

(B)

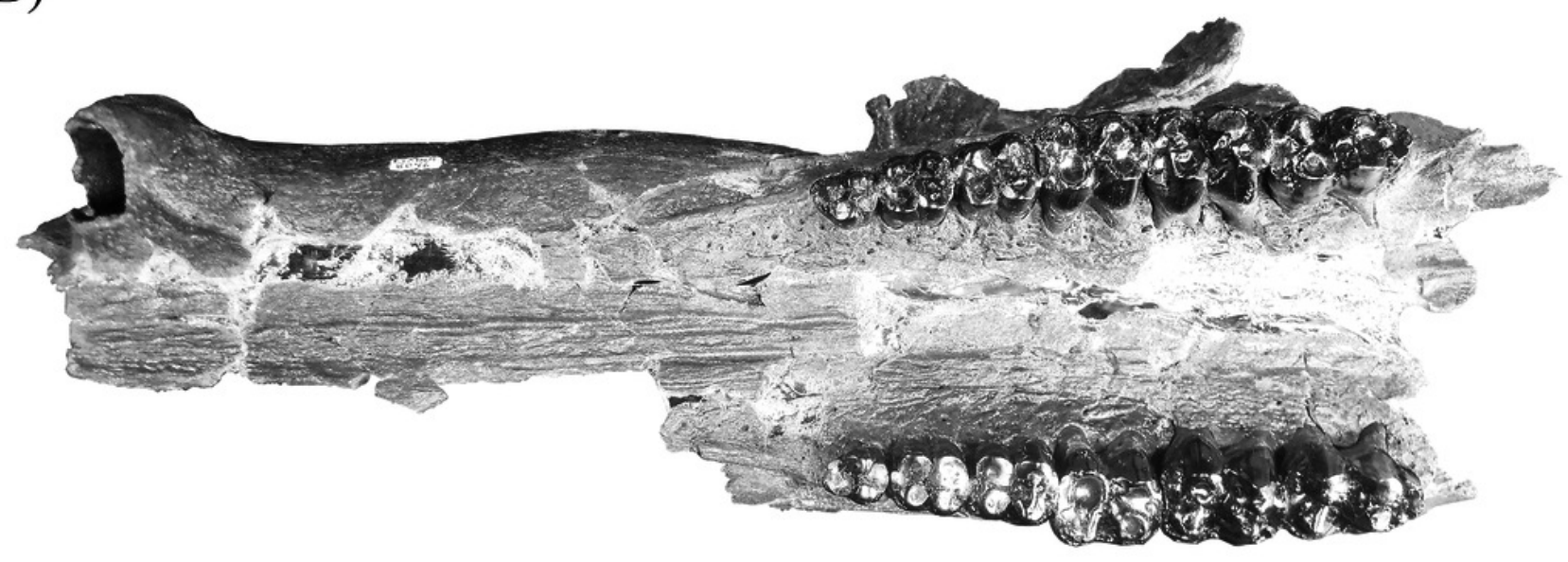

(C)

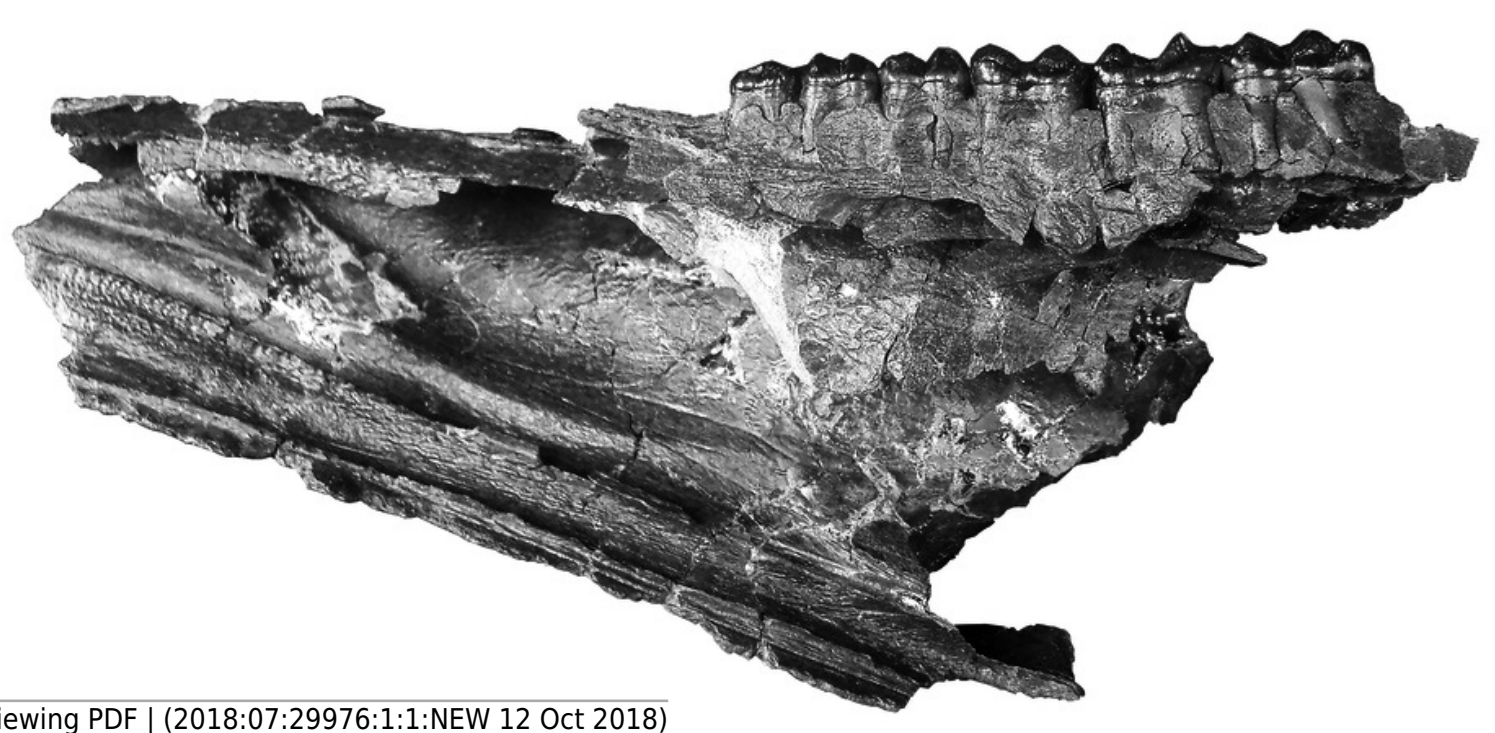




\section{Figure 5}

Lateral (A) and buccal (B) view of mandible, ETMNH 8046, of Mylohyus elmorei bearing right p2-m3 and left p3-m3.

Image is in grayscale to prevent morphologies from being obscured due to coloration.

(A)

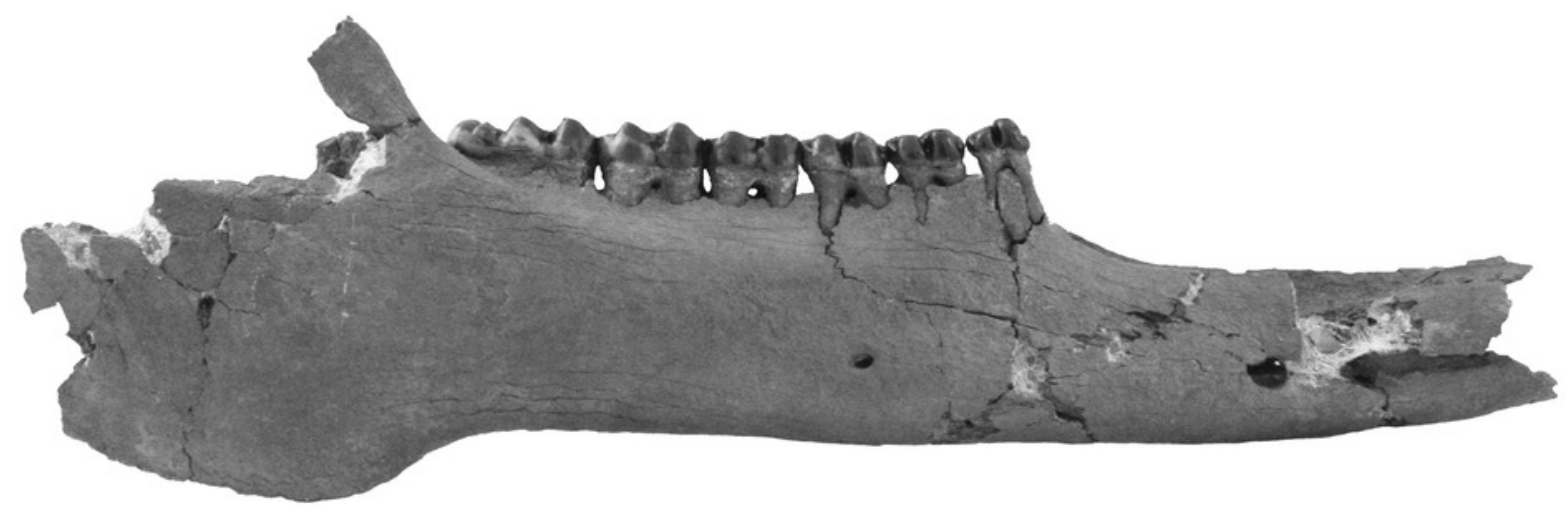

(B)

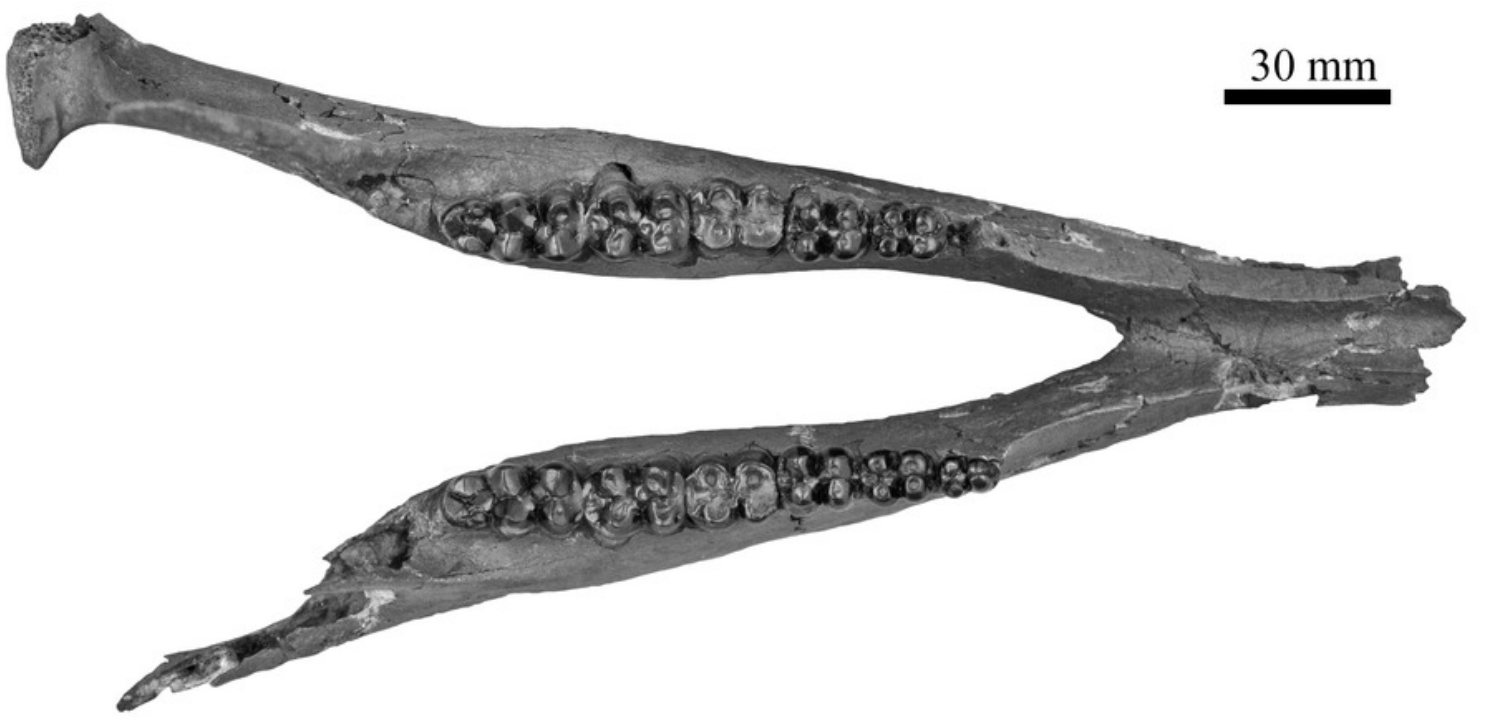




\section{Figure 6}

Upper dentitions of Gray Fossil Site and Palmetto Fauna Mylohyus elmorei.

Specimens observed include UF/TRO 440 (A), UF 203540 (B), UF 12265 (C), ETMNH 8046 (D), and ETMNH 7279 (E). Image is in grayscale to prevent morphologies from being obscured due to coloration.
(A) UF/TRO
(B) UF 203540
(C) UF 12265
(D) ETMNH 8046
(E) ETMNH 7279 440
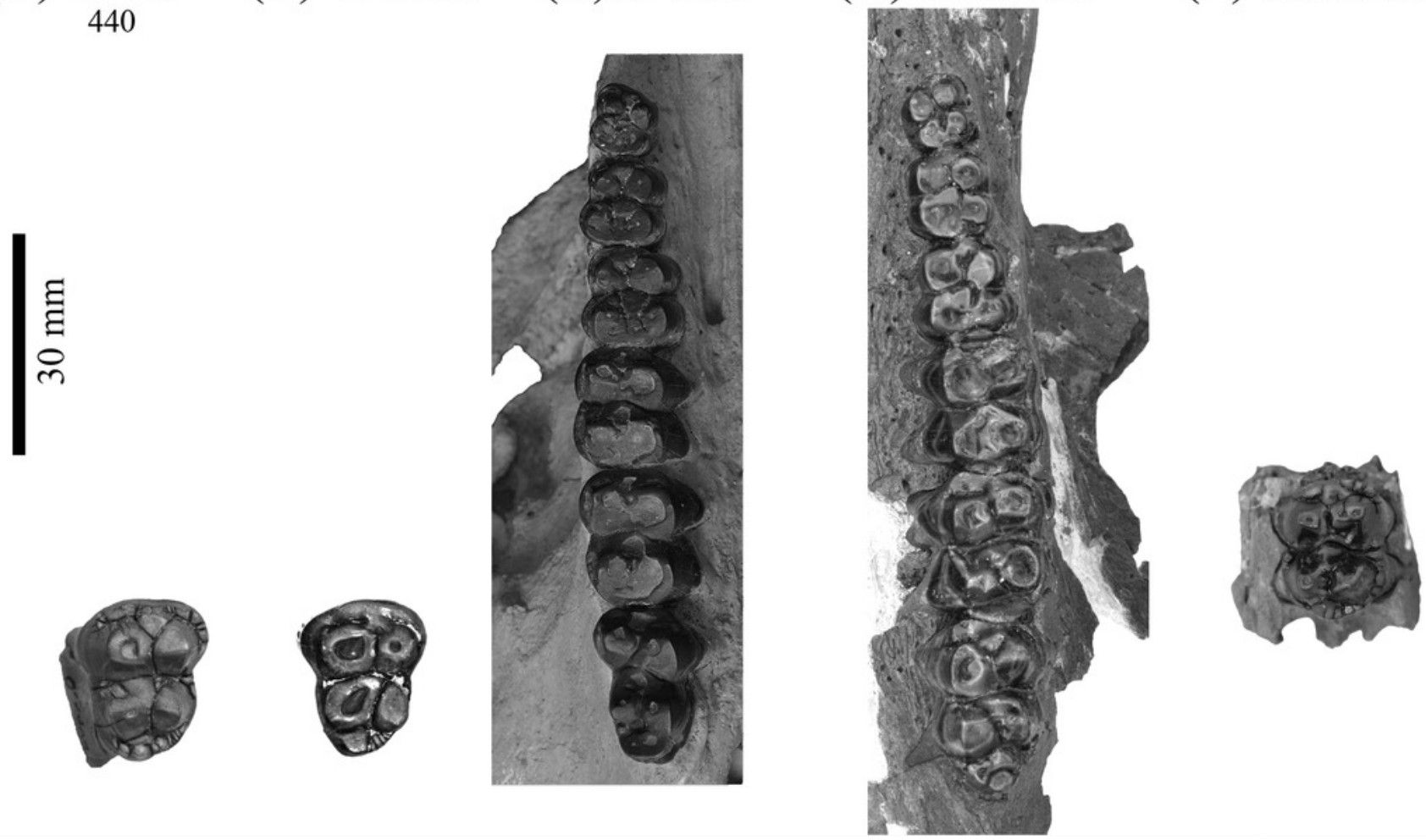


\section{Figure 7}

Lower dentition of Mylohyus elmorei.

Observed specimens are ETMNH 17219 (A), ETMNH 19281 (B), ETMNH 8046 (C), UF/TRO 412 (D), and UF 294749 (E). Image is in grayscale to prevent morphologies from being obscured due to coloration.
(A) ETMNH
(B) ETMNH
(C) ETMNH 8046
(D) UF/TRO 412
(E) UF 294749
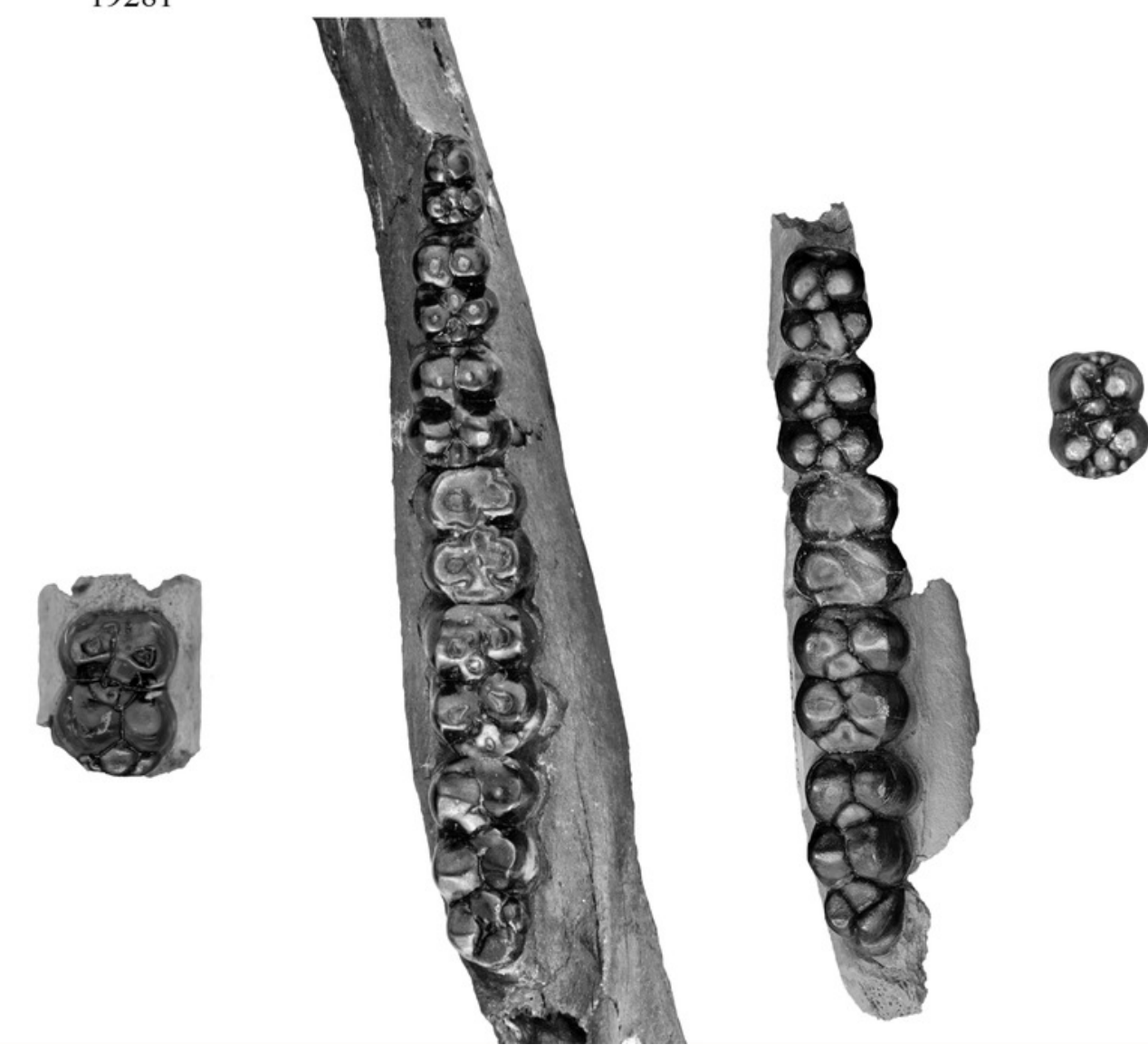


\section{Figure 8}

Partial crania, ETMNH 8046 (A) and UF 12265 (B), of Mylohyus elmorei in occlusal view.

Image is in grayscale to prevent morphologies from being obscured due to coloration.

(A)
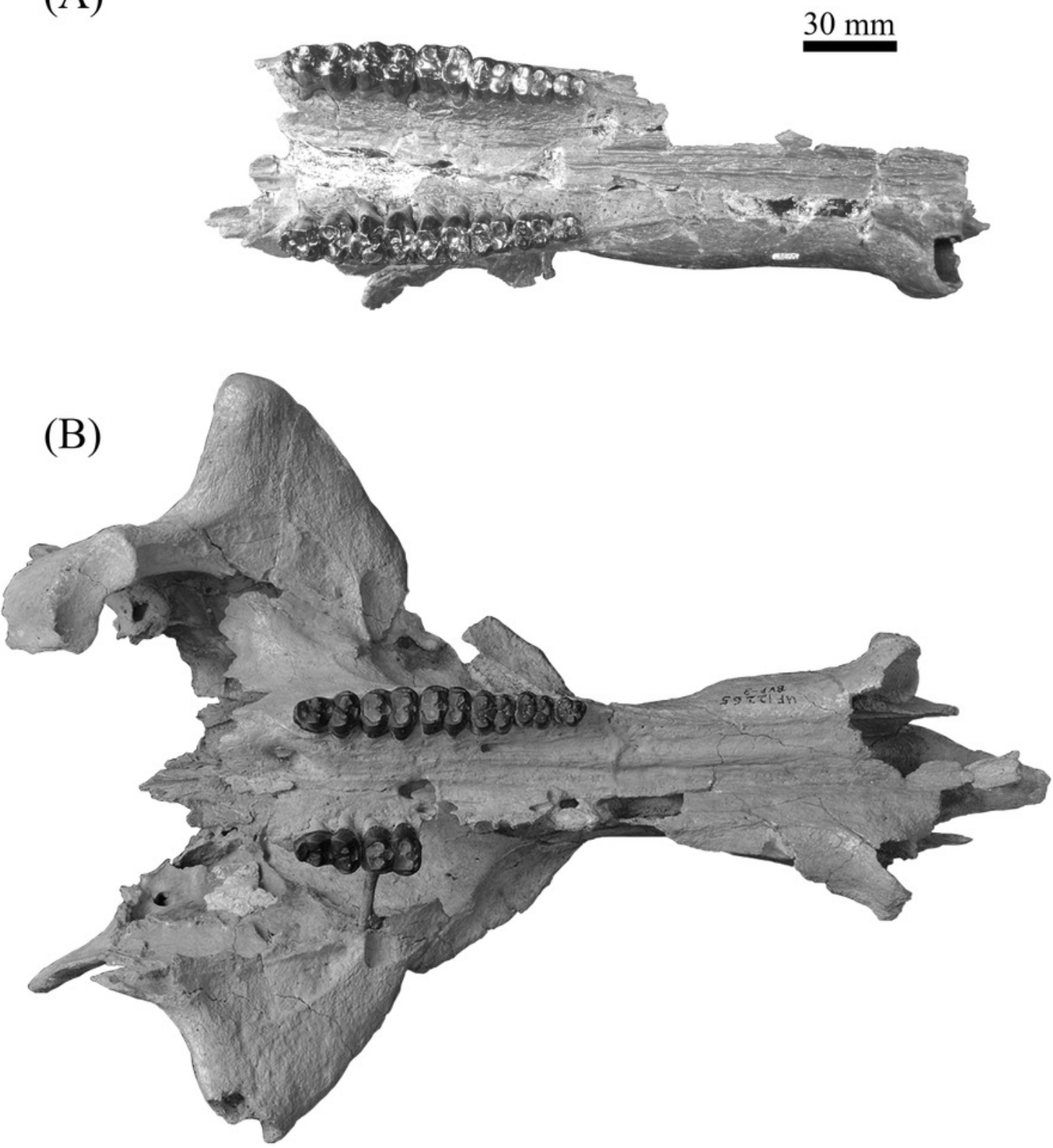


\section{Figure 9}

Partial crania, ETMNH 8046 (A) and UF 12265 (B), of Mylohyus elmorei in dorsal view.

Image is in grayscale to prevent morphologies from being obscured due to coloration.

(A)
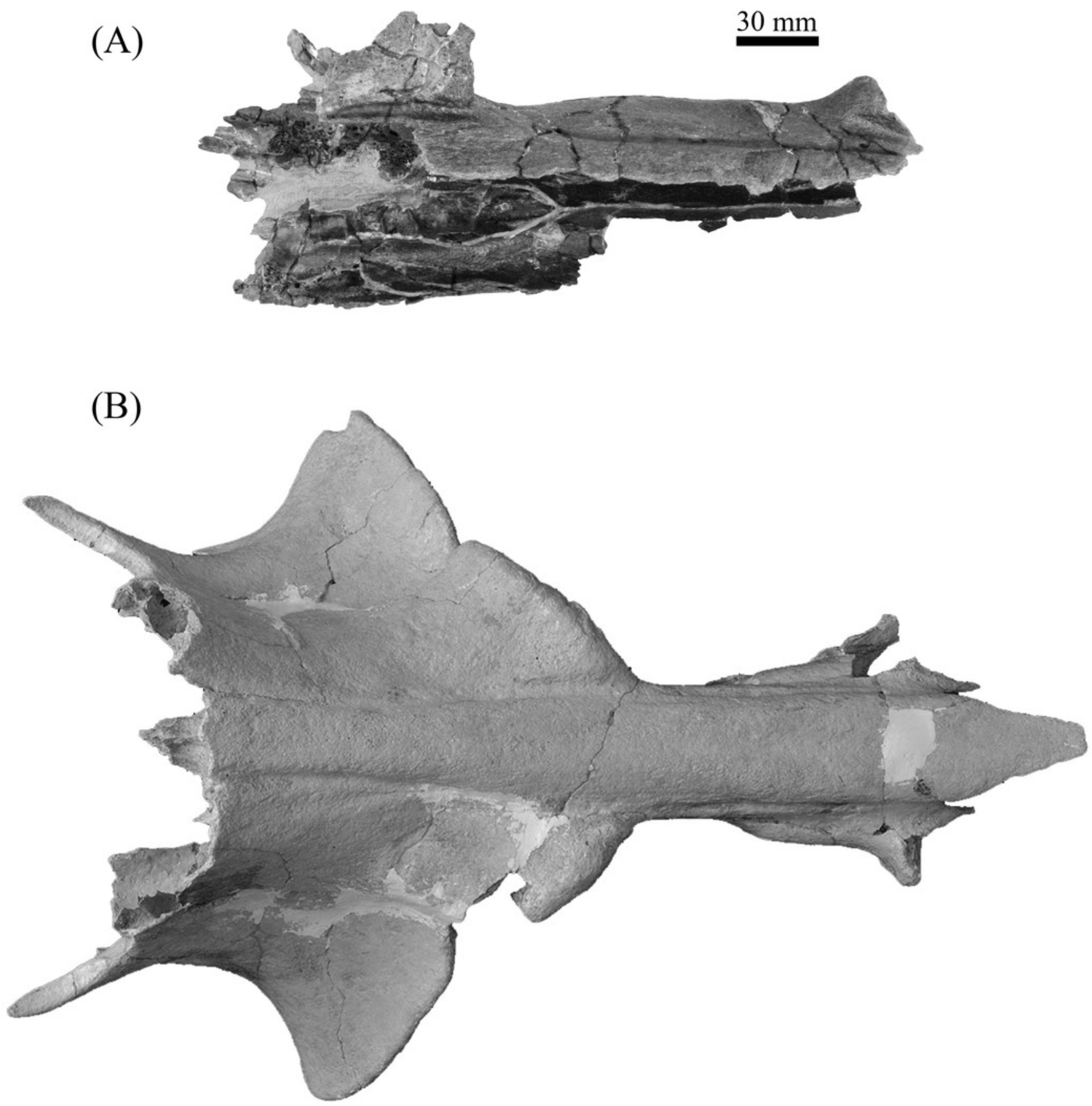


\section{Figure 10}

Comparison of partial Prosthennops cf. P. serus and Prosthennops serus mandibles, UF 212306 ( $A$ and C) and ETMNH 5615 (B and D), respectively.

Image is in grayscale to prevent morphologies from being obscured due to coloration.

(A)

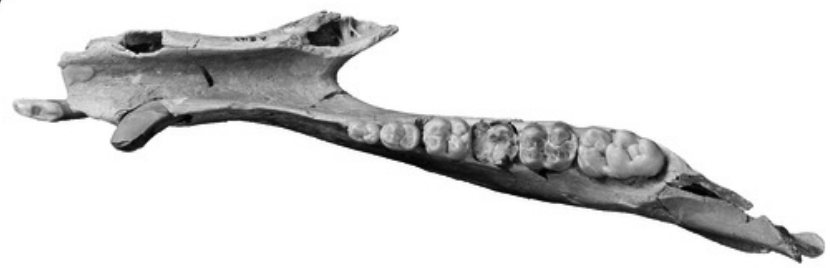

(B)

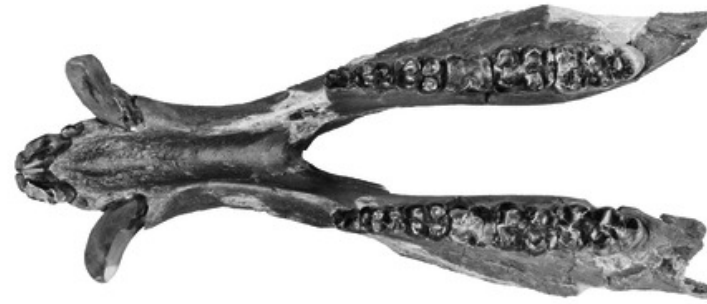

(C)

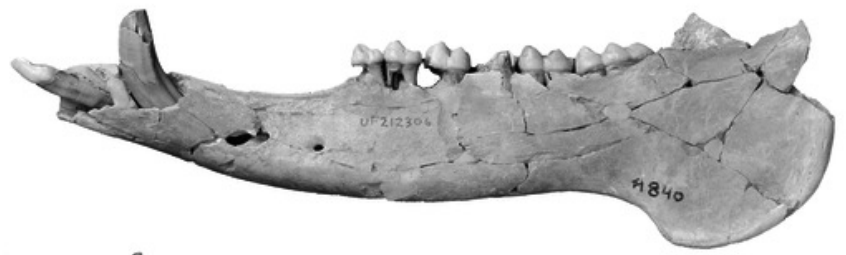

$30 \mathrm{~mm}$
(D)

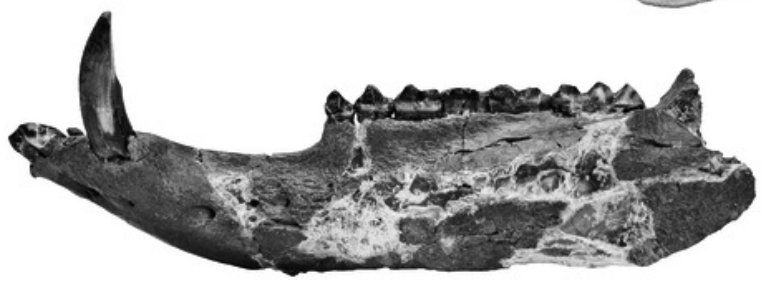




\section{Figure 11}

Comparison of lower dentition of Prosthennops serus and Prosthennops cf. $P$. serus.

Observed specimens: ETMNH 5615 (A), UF/TRO 413 (B), UF 212306 (C), and UF 220251 (D). Image is in grayscale to prevent morphologies from being obscured due to coloration.
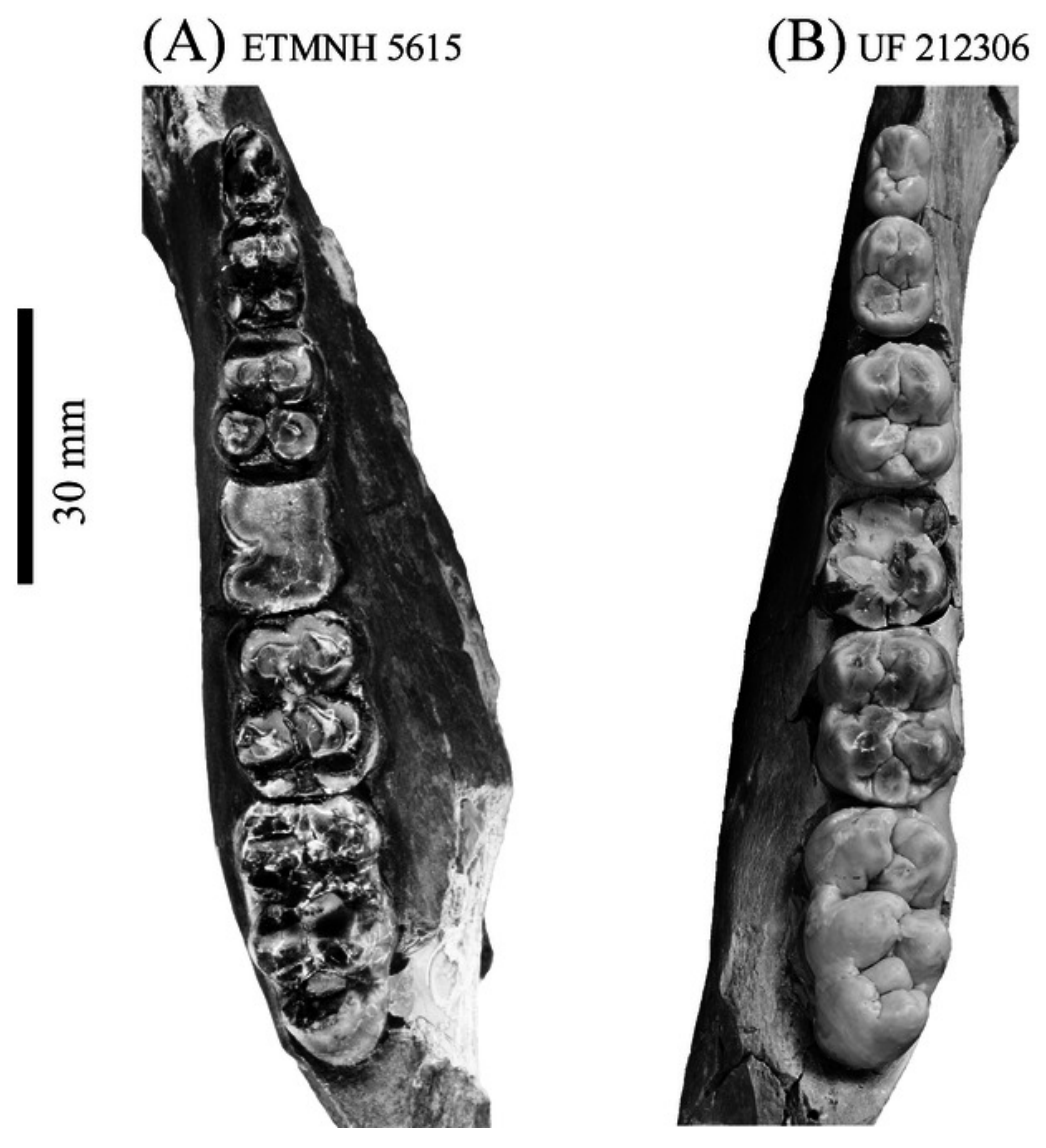

(C) UF/TRO 413

(D) UF 220251
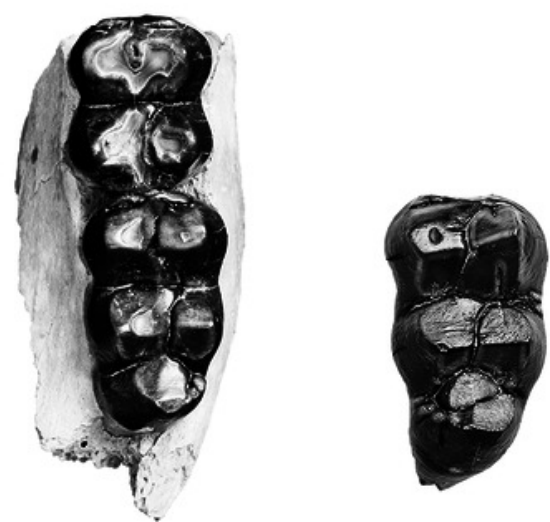